UNIVERSIDADE DE SÃO PAULO

ESCOLA DE ENFERMAGEM

CAROLINA LUIZA BERNARDES

A VIVÊNCIA DOS TRABALHADORES DE ENFERMAGEM QUE SOFRERAM ACIDENTE COM FLUIDO BIOLÓGICO:

UM OLHAR FENOMENOLÓGICO

São Paulo

2014 


\section{A VIVÊNCIA DOS TRABALHADORES DE ENFERMAGEM QUE SOFRERAM ACIDENTE COM FLUIDO BIOLÓGICO: UM OLHAR FENOMENOLÓGICO}

Dissertação apresentada ao Programa de PósGraduação em Gerenciamento em Enfermagem da Escola de Enfermagem da Universidade de São Paulo para obtenção do título de Mestre em Ciências

Área de Concentração: Fundamentos e Práticas de Gerenciamento em Enfermagem e em Saúde.

Orientadora:

Prof. ${ }^{\text {a }}$ Dr. ${ }^{\text {a }}$ Patrícia Campos Pavan Baptista

São Paulo 
Autorizo a reprodução total ou parcial deste trabalho, por qualquer meio convencional ou eletrônico, para fins de estudo e pesquisa desde que citada à fonte.

Assinatura:

Data:

\section{Catalogação na Publicação (CIP)}

Biblioteca "Wanda de Aguiar Horta"

Escola de Enfermagem da Universidade de São Paulo

Bernardes, Carolina Luiza

A vivência dos trabalhadores de enfermagem que sofreram acidente com fluído biológico: um olhar fenomenológico / Carolina Luiza Bernardes. São Paulo, 2014.

$96 \mathrm{p}$.

Dissertação (Mestrado) - Escola de Enfermagem da Universidade de São Paulo.

Orientadora: Prof. a Dr. ․ Patrícia Campos Pavan Baptista

Área de concentração: Fundamentos e Práticas de Gerenciamento em Enfermagem e em Saúde

1. Enfermagem. 2. Agentes biológicos. 3. Pesquisa qualitativa. I. Título. 


\section{FOLHA DE APROVAÇÃO}

Nome: Carolina Luiza Bernardes

Titulo: A vivência dos trabalhadores de enfermagem que sofreram acidente com fluido biológico: um olhar fenomenológico.

Dissertação apresentada ao Programa de Pós-

Graduação em Gerenciamento em Enfermagem da Escola de Enfermagem da Universidade de São Paulo para obtenção do título de Mestre em Ciências.

Aprovado em:

\section{Banca Examinadora}

Prof. Dr.:

Instituição:

Julgamento:

Assinatura:

Prof. Dr.:

Instituição:

Julgamento:

Assinatura:

Prof. Dr.:

Instituição:

Julgamento:

Assinatura: 
Dedicatória

Aos mens pais Lincoln e Maria pelo amor incondicional, e por terem nos mostrado o Grilhante caminho dos estudos.

A minha irmã Amália pela dedicasaño e companheirismo.

A minha irmã Natália por estar sempre tão perto mesmo estando longe.

A minha tia e madrinha Márcia pelo carinho dedicado a nós. 


\section{AGRADECIMENTOS}

A Nossa Senhora Aparecida pela Graça alcançada.

A Profa. Patricia Campos Pavan Baptista pelas orientacões, por ter possibilitado meu ingresso no Mestrado e por contribuir de forma significativa com o meu trabalho e meu crescimento como pesquisadora.

A Profa. Vanda Elisa Andres Felli pela experiência e palavras sábias durante as reuniões do grupo de pesquisa.

As Profar Arlete Silva e Miriam Merigui pelas valiosar contribuiçöes duranteo exame de qualificação.

Aos pesquisadores do grupo de pesquisa pelo coleguismo e aprendizado compartilhado durante nossas reuniões.

A equipe do SESUT Dr. Eduardo Costa Sá e aos enfermeiros Thatiana Fernanda Coa, Ruth Munhoz, Elza Leandro da Silva, Ricardo Roslindo e Vania Germinia Andrade pelo apoio, receptividade e ajuda durante todo o Mestrado.

As trabalhadoras de enfermagem que por meio do relato de suas vivencias possibilitaram a reflexão e elaboracão deste trabalho.

A Clotilde Aparecida C. Silva da Biblioteca da Escola de Enfermagem pelo seu Grilhante trabalho.

Ao fotógrafo Lincoln Bernardes que gentilmente cedeu suar fotos para publicação neste trabalho.

A Fundacão de Amparo à Pesquisa do Estado de São Paulo pelo financiamento deste estudo. 
"O ente que temos a tarefa de analisar somos nós mesmos. O ser deste ente é sempre e cada vez meu."

Martin Heidegger 
Bernardes CL. A vivência dos trabalhadores de enfermagem que sofreram acidente com fluido biológico: um olhar fenomenológico [dissertação]. São Paulo: Escola de Enfermagem, Universidade de São Paulo; 2014.

\section{RESUMO}

A exposição ocupacional aos fluidos biológicos é inerente ao trabalho desempenhado pela equipe de enfermagem durante a realização da assistência, tornando o trabalhador susceptível a ocorrência de acidentes e exposto aos fluidos corporais que podem conter diferentes patógenos causadores de doenças como HIV, Hepatite B e C. Trata-se de um estudo de natureza qualitativa que objetivou compreender a experiência do acidente com fluido biológico e da assistência prestada aos trabalhadores de enfermagem, considerando suas necessidades de cuidado. Foram realizadas entrevistas individuais a partir da seguinte questão norteadora: "Conte-me como foi para você ter se acidentado com fluido biológico?". Os discursos foram analisados à luz do Referencial de Martin Heidegger onde surgiram as seguintes Unificações Ontológicas: Ser no mundo vivenciando a acidente com fluido biológico; A angústia por ter se acidentado com fluido biológico; As necessidades manifestas pelas trabalhadoras de enfermagem após o acidente com material biológico: vivenciando o cuidado autêntico; Vivenciando o cuidado inautêntico e a impessoalidade após o acidente de trabalho com material biológico; Superação e reorganização do trabalho por meio da transcendência. Os resultados demonstram que após o acidente com fluido biológico as trabalhadoras vivenciam a angústia e a assistência à trabalhadora acidentada é efetiva quanto ao acompanhamento clínico e ambulatorial por meio do protocolo de atendimento, porém ele não aborda questões consideradas fundamentais no ponto de vista do sujeito que sofre o acidente.

Palavras-chave: Enfermagem. Exposição ocupacional. Agentes biológicos. Pesquisa qualitativa. 
Bernardes CL. The experience of nursing staff who had accidents with biological fluid: a phenomenological look [dissertation]. São Paulo: Escola de Enfermagem, Universidade de São Paulo; 2014.

\section{ABSTRACT}

Occupational exposure to biological fluids is inherent in the work performed by the nursing staff during the implementation of assistance, making the worker liable to accidents and exposed to body fluids that may contain various pathogens causing diseases like HIV, Hepatitis B and C. This is a qualitative study that aimed to understand the experience of the accident with biological fluid and assistance to the nursing staff, considering their care needs. Individual interviews were conducted with the following question: "Tell me how it was for you to have crashed with biological fluid?". The reports were analyzed in the light of Martin Heidegger Referential where Ontological Unifications following emerged: Being in the world experiencing the accident with biological fluid ; The anguish because you are injured in biological fluid; The manifest need for nursing workers after the accident with biological material : experiencing authentic care ; Experiencing care inauthentic and impersonality after work accident with biological material ; Resilience and reorganization of work through transcendence. The results show that after the accident with biological fluid workers experience distress and assisting rugged working is effective for clinical and outpatient follow- through care protocol, but it does not address fundamental issues considered in view of the individual who suffers the accident

Keywords: Nursing. Occupational exposure. Biological Agents. Qualitative research. 


\section{SUMÁRIO}

Dedicatória

Agradecimentos

Resumo

Abstract

1. INTRODUÇÃO .11

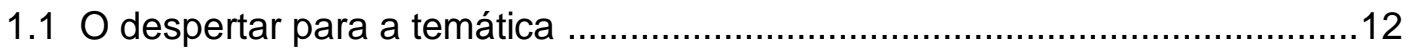

1.2 Inquietações e o objetivo do estudo ...........................................................13

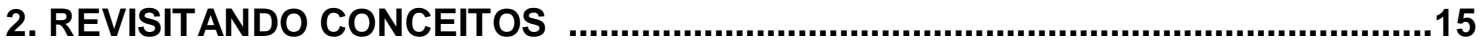

2.1 O trabalhador de enfermagem e o acidente com fluido biológico ..................16

2.2 A assistência ao trabalhador acidentado com fluido biológico: notificação do acidente, profilaxia após a exposição e monitoramento

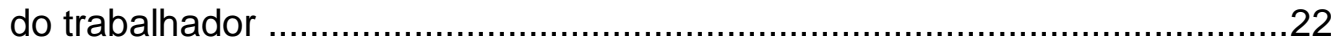

3. OPTANDO PELO MÉTODO QUALITATIVO FENOMENOLÓGICO ........................29

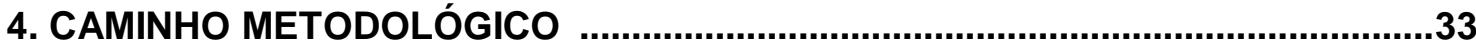

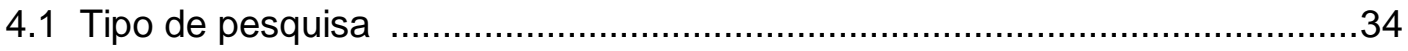

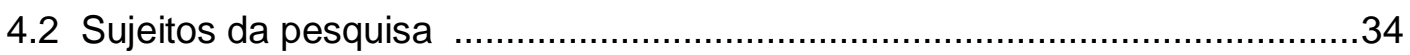

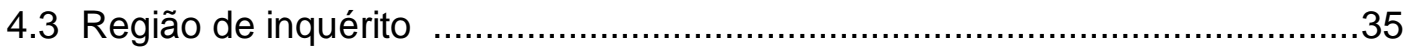

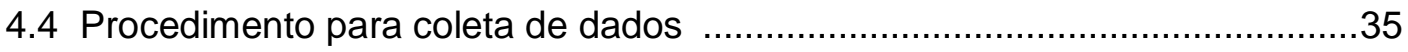

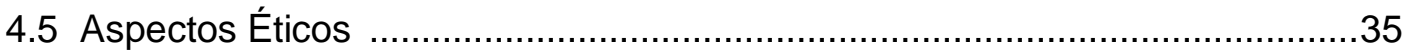

4.6 O caminho para a Análise dos discursos ......................................................36

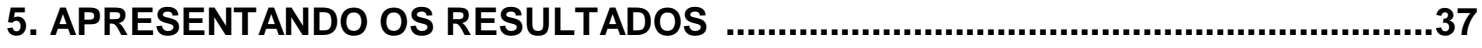

5.1 Conhecendo as trabalhadoras de enfermagem que sofreram acidente

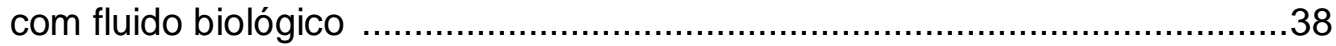

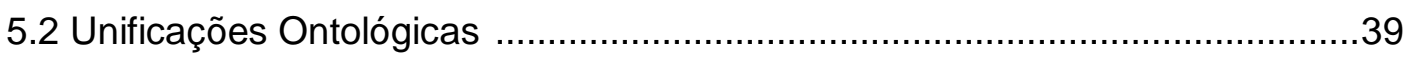

5.2.1 Ser no mundo vivenciando o acidente com fluido biológico ...................39

5.2.2 A angústia por ter se acidentado com fluido biológico ...........................43

5.2.3 As necessidades manifestas pelas trabalhadoras de enfermagem após o acidente com fluido biológico: vivenciando o cuidado autêntico

5.2.4 Vivenciando o cuidado inautêntico e a impessoalidade após o acidente de trabalho com fluido biológico

5.2.5 Superação e reorganização do trabalho por meio da

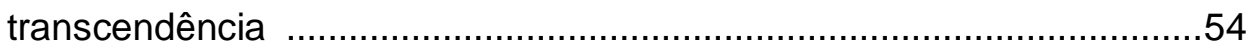

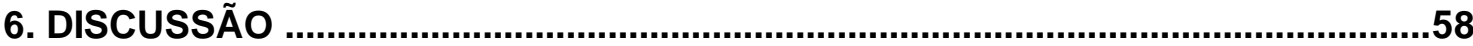

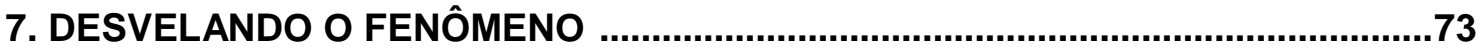

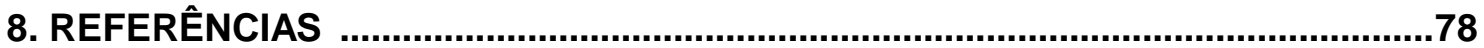

9. APÊNDICES

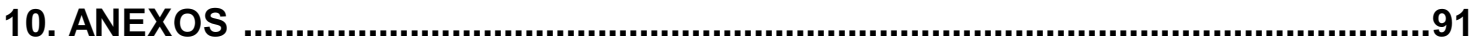




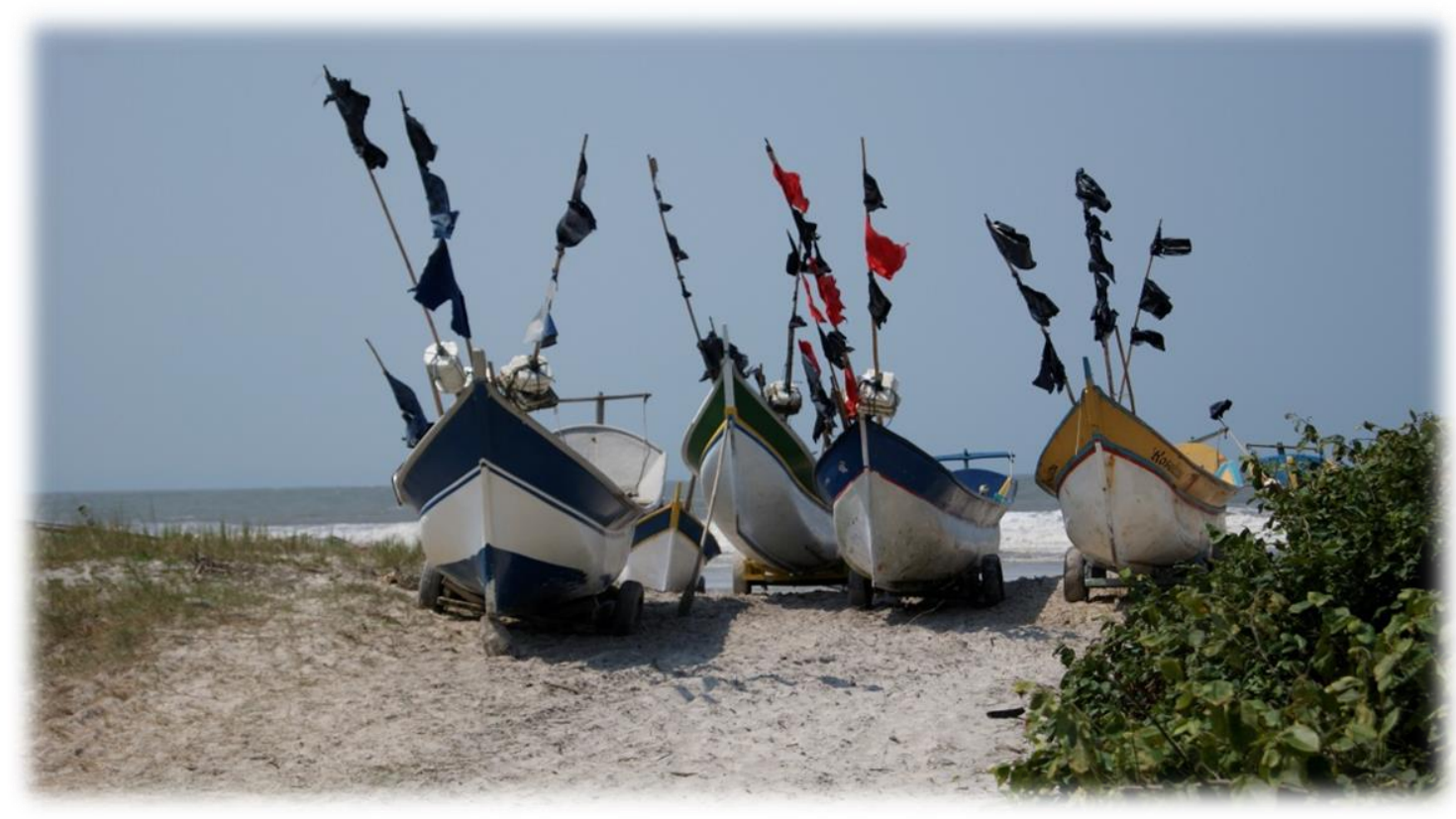

1. INTRODUÇÃO 


\subsection{0 despertar para a temática}

Iniciei minha trajetória profissional no ano de 2009, em uma unidade de emergência de um hospital escola, considerado o maior complexo hospitalar da América Latina. O primeiro contato foi marcante, inúmeros pacientes com diferentes patologias e um avanço tecnológico diário exigindo constante atualização por parte de todos os trabalhadores.

No decorrer da minha atuação fui me inquietando com as questões relativas à suscetibilidade aos acidentes de trabalho, em especial aos acidentes com fluidos biológicos, considerando a rotina frenética, a alta demanda de pacientes e o trabalho intenso devido à rapidez nos atendimentos e a gravidade das emergências. Inúmeras vezes compartilhei o desgaste de colegas após um acidente de trabalho com fluido biológico, tendo em vista a incerteza relacionada ao estado de saúde dos pacientes e, frequentemente a ausência de exames sorológicos, por se tratar de uma unidade emergencial.

É importante ressaltar que o trabalhador imerso em seu cotidiano de trabalho ao se deparar com uma situação inesperada necessita de apoio institucional no sentido de facilitar seu acesso ao atendimento rápido e que the proporcione segurança e acolhimento em um momento tão angustiante. Entretanto, minha experiência profissional permitiu-me a percepção de que os serviços nem sempre têm uniformidade nas orientações e no atendimento desses trabalhadores, decorrente de dúvidas acerca dos protocolos, gerando ansiedade e agravando ainda mais o contexto vivencial dos trabalhadores acidentados.

Outro fator observado foi a subnotificação dos acidentes pelos profissionais expostos, o que pode estar relacionado ao medo da exposição no ambiente laboral, punições como a perda do emprego, e a própria falta de informações acerca do protocolo preconizado na instituição.

É inegável o avanço no conhecimento sobre os acidentes com fluidos biológicos, nas pesquisas quantitativas e qualitativas, que abordam não 
apenas os dados referentes à ocorrência dos acidentes como os sentimentos vivenciados pelos trabalhadores, porém ainda é problemática a situação dos trabalhadores de enfermagem quanto à notificação dos acidentes, o seguimento do protocolo, o que pode indicar uma assistência ineficaz ao trabalhador e uma fragilidade nos sistemas de vigilância de notificação desses acidentes.

Nesse aspecto, esta pesquisa surge com 0 intuito de desvelar 0 fenômeno ser trabalhador de enfermagem e ter se acidentado com fluido biológico, considerando as lacunas existentes acerca da assistência prestada ao trabalhador acidentado bem como suas necessidades de cuidado. Considerando que por meio da investigação fenomenológica é possível descobrir os significados ocultos vivenciados por cada indivíduo em determinada situação e suas repercussões para sua vida profissional, social e afetiva, acredito que este estudo poderá subsidiar mudanças relacionadas à assistência prestada aos trabalhadores de enfermagem vítimas de acidentes com fluidos biológicos.

A seguir apresento as inquietações que me conduziram à realização da presente pesquisa.

\subsection{Inquietações e o objetivo do estudo}

Diante da experiência vivenciada durante minha atuação na Unidade de Pronto Socorro, surgiram algumas inquietações acerca das vivências dos trabalhadores que se acidentaram com fluidos biológicos:

* Em que contexto de trabalho os acidentes com fluido biológico ocorrem?

Como é a assistência prestada ao trabalhador acidentado com fluido biológico? 
* Quais são as necessidades de cuidado manifestas pelos trabalhadores de enfermagem acidentados?

* Quais as dificuldades encontradas pelos trabalhadores que se acidentaram com fluido biológico?

Este estudo tem como objetivo compreender a experiência do acidente com fluido biológico e da assistência prestada aos trabalhadores de enfermagem, considerando suas necessidades de cuidado. Compreender a vivência dos trabalhadores de enfermagem que se acidentaram com fluidos biológicos poderá desvelar o sentido do acidente para o trabalhador no tocante à assistência recebida fornecendo subsídios para o desenvolvimento de medidas de proteção à saúde do trabalhador, indicando as possíveis lacunas no processo de atendimento que podem favorecer a subnotificação desses acidentes bem como o não seguimento do tratamento por parte dos trabalhadores tendo em vista a melhoria da assistência aos trabalhadores vitimados com esta natureza de acidente e o desenvolvimento de estratégias para a criação de um sistema eficaz de vigilância e monitoramento dos acidentes de trabalho com fluidos biológicos.

Dessa forma, considero importante apresentar ao leitor o contexto atual dos acidentes de trabalho com fluido biológico nos trabalhadores de enfermagem. O capítulo a seguir propõe uma revisão de literatura. 


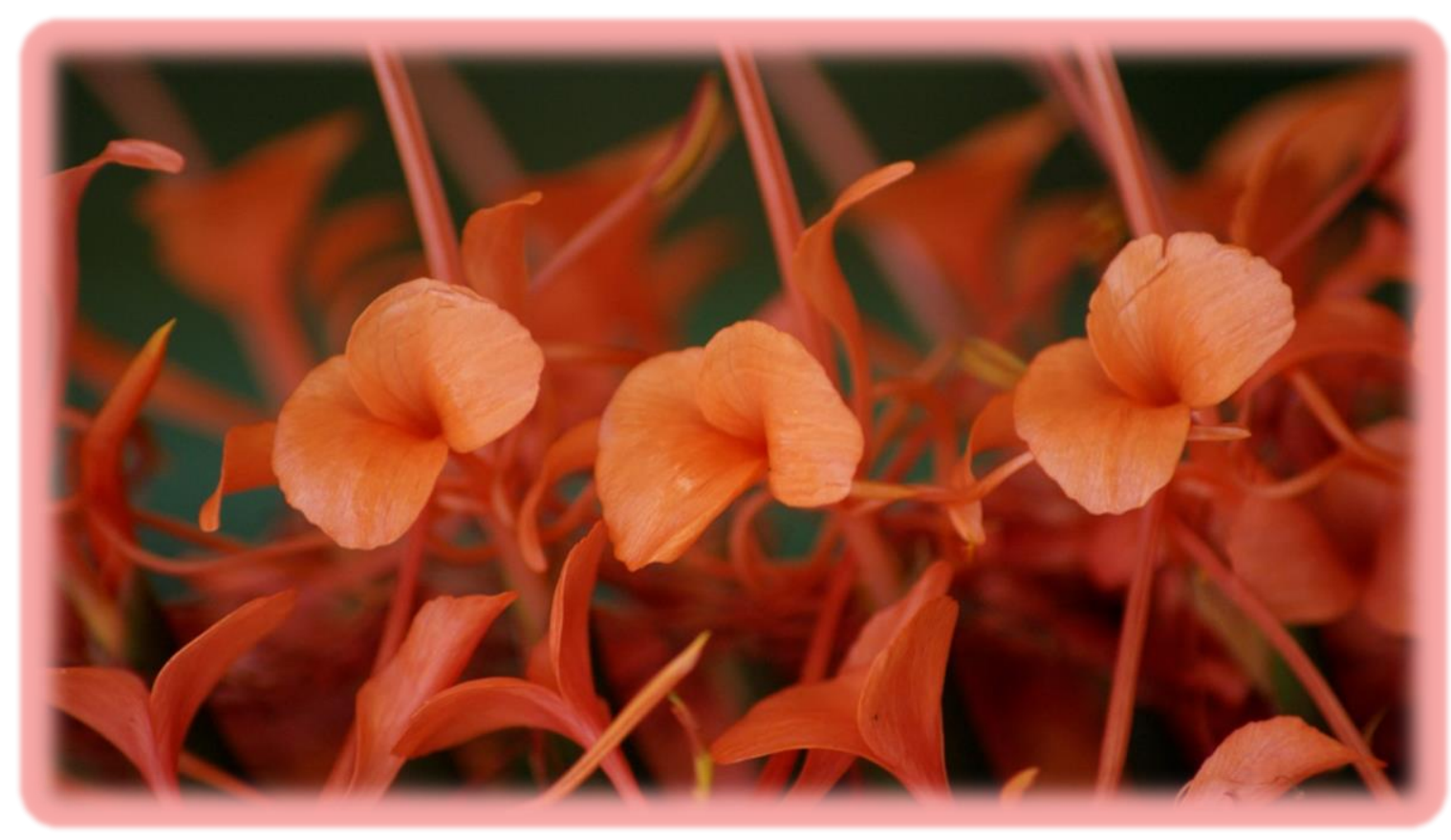

2. REVISITANDO CONCEITOS 


\subsection{O trabalhador de enfermagem e o acidente com fluido biológico}

Os trabalhadores de enfermagem estão expostos às cargas biológicas, químicas, físicas, fisiológicas e psíquicas durante o processo de trabalho. Partindo-se da abordagem histórica da saúde do trabalhador de enfermagem, durante o processo de trabalho essas cargas interagem entre si e com o corpo do trabalhador podendo gerar processos de desgaste, inclusive com perda da capacidade laboral (Laurell,Noriega,1989).

Os acidentes de trabalho são formas de expressão do desgaste do trabalhador. Ao sofrer um acidente ocupacional o trabalhador é exposto às cargas biológicas devido ao contato direto com fluidos biológicos seja através de respingos, perfuração da pele ou contato com mucosas, às cargas mecânicas devido aos cortes e rompimento da solução de continuidade da pele nos casos de acidentes com perfurocortantes e as cargas psíquicas muitas vezes subjugadas pelos próprios profissionais e relacionada aos sentimentos vivenciados durante e após o acidente ((Felli,Tronchin 2010).

De acordo com a Lei no 8.213/91, acidente de trabalho é o que ocorre pelo exercício do trabalho a serviço da empresa ou pelo exercício do trabalho dos segurados, provocando lesão corporal ou perturbação funcional que cause a morte, perda ou redução, permanente ou temporária, da capacidade para o trabalho (Brasil, 1991).

Durante a realização da assistência de enfermagem devido à manipulação de materiais como lâminas, cateteres, sondas e na execução de procedimentos invasivos o trabalhador entra em contato direto com fluidos orgânicos e secreções tornando-se susceptível à ocorrência de acidentes que o expõe a patógenos causadores de doenças como os vírus HIV, hepatite B e C (Pinheiro, Zeitoune, 2008; Marziale, Nishimura, 2003).

Entre os acidentes causados por fluido biológico entre a sua maioria estão aqueles com materiais perfurocortantes e a categoria profissional mais atingida, é a dos auxiliares de enfermagem. O maior número de acidentes 
ocorre durante a realização de procedimentos, cuidados ao paciente no leito como punção venosa, aspiração e administração de medicamentos. As literaturas nacionais e internacionais apontam que as mãos foram a parte do corpo mais envolvida em acidentes (Mbaisi et al.,2013; Gomes et al.,2009; Spagnuolo, Baldo, Guerrini, 2008).

Uma pesquisa realizada em Ribeirão Preto (SP) demonstrou a ocorrência de 140 acidentes de trabalho em um período de seis meses, os trabalhadores da equipe de enfermagem registraram 45 (72,5\%) dos acidentes de trabalho com exposição a fluidos biológicos, desses 42 (67,7\%) eram auxiliares e técnicos de enfermagem (Giomo et al.,2009).

Em um estudo realizado no Hospital universitário da Universidade de São Paulo, foi identificado que dos 46 acidentes com exposição a fluidos biológicos ocorridos durante o período de um ano, (73\%) ocorreram com os trabalhadores de enfermagem. A unidade de emergência foi o local onde ocorreu a maior parte dos acidentes, seguida pela clínica médica e unidade de terapia intensiva (Balsamo, Felli, 2006).

As exposições ocupacionais que podem causar a transmissão do vírus HIV e dos vírus da Hepatite $\mathrm{B}(\mathrm{HBV})$ e $\mathrm{C}(\mathrm{HCV})$ ao trabalhador podem ocorrer por meio de uma lesão percutânea (corte com objeto pontiagudo, bisturi ou agulha) e pelo contato da mucosa ou pele não íntegra com sangue ou outros fluídos corporais que são potencialmente infecciosos. O risco de transmissão do vírus HIV é de $0,3 \%$ em casos de exposição percutânea e $0,09 \%$ em acidentes envolvendo mucosas. O sangue é o principal meio transmissor de hepatite $\mathrm{B}$, ० HBsAg é o antígeno de superfície do vírus e HBeAg é o antígeno que indica a replicação viral, indicando o aumento da carga viral, nesses casos o risco de hepatite clínica é de 22 a 31\%, nos casos onde apenas HBsAg é detectado no paciente fonte o risco fica em torno de 1 a $6 \%$. Em relação ao vírus da Hepatite $\mathrm{C}$ a transmissão só ocorre de maneira efetiva através do sangue, considera-se que a transmissão do vírus através de outros fluidos biológicos é muito baixa e o índice de soroconversão em casos 
de sangue infectado é de 1,8\% (Centers for disease Control and Prevention, 2005; Brasil, 2004;).

Um estudo realizado a partir dos acidentes com fluido biológico ocorridos na Grande Florianópolis no ano de 2007 demonstrou que, do número total de acidentes no período, 73\% envolveram exposição percutânea, $10 \%$ através das mucosas e pele íntegra respectivamente, seguidos por aqueles relacionados à exposição da pele não íntegra igual a 7\% (Vieira, Padilha, Pinheiro, 2011).

É importante ressaltar que aspectos relacionados ao descarte de materiais perfurocortantes como o preenchimento das caixas coletoras acima do recomendado pelo fabricante bem como a prática de depositar materiais contaminados com sangue em caixas já preenchidas, por meio de manobras como empurrar os materiais com as mãos aumentam o risco de perfuração. Soma-se a esses fatores o hábito de reencapar agulhas que ainda se faz presente e interfere negativamente na prevenção dos acidentes.

O primeiro caso de exposição ocupacional ao HIV seguido de contaminação data de 14 de Outubro de 1994, em um Hospital privado na cidade de São Paulo. O acidente ocorreu quando um auxiliar de enfermagem perfurou o braço direito ao ajudar um colega durante uma punção venosa em um paciente com diagnóstico de AIDS. Após a exposição, o profissional não recebeu nenhuma medicação profilática, pois no período do acidente não existia no Brasil qualquer recomendação oficial para sua utilização. Após uma sucessão de testes com resultados negativos para HIV, em 1996, o profissional foi submetido a um teste Elisa e posteriormente ao Western-Bloth ambos com resultados positivos (Santos, Monteiro, Ruiz, 2002).

Nesse sentido, estudo que propôs analisar as causas dos acidentes a partir da percepção do profissional acidentado aponta como resultados o descuido do trabalhador, a sobrecarga de trabalho, os riscos inerentes à 
profissão, a falta de materiais e infraestrutura inadequados e a não observação das medidas de proteção (Damasceno et al.,2006).

Os fatores de risco para acidentes de trabalho com material perfurocortante estão associados ao não cumprimento das normas de biossegurança e ao não conhecimento das mesmas, falta de atenção e planejamento na execução das atividades e sobrecarga de trabalho devido ao número reduzido de profissionais responsáveis pelos cuidados aos pacientes (Alves, Passos, Tocantins,2009).

É sabido que as medidas de proteção não foram amplamente incorporadas as rotinas pelos trabalhadores de enfermagem e embora sejamos um grupo altamente exposto aos fluidos biológicos, nota-se que a adesão ao uso de equipamentos de proteção individual ainda é baixa nos tornando ainda mais vulneráveis (Nichiata, Takahashi, Ciosak, 2004).

Frequentemente, observa-se que os trabalhadores de enfermagem subjugam os riscos aos quais estão expostos ao desenvolverem suas rotinas de trabalho, a não utilização de luvas para a realização de punção venosa, a ausência do uso de máscara e óculos de proteção durante a execução de procedimentos como sondagem vesical e aspiração endotraqueal, são práticas corriqueiras nas instituições de saúde. Cercados por uma rotina desgastante e a segurança proporcionada pelos anos de ocupação torna os trabalhadores pouco reflexivos em relação à importância da utilização dos equipamentos de proteção individual para a sua saúde.

O uso das precauções universais e o desenvolvimento de estratégias para o seu uso durante o processo de trabalho é a principal e mais eficaz medida para a prevenção de acidentes entre os trabalhadores (Garner, Salehi, 2010;Brasil,2006). As precauções padrão recomendam o uso de equipamentos de proteção individual (EPIs) durante a realização da assistência aos pacientes, independente do seu diagnóstico e o não reencape das agulhas após a sua utilização. Os trabalhadores devem usar máscara, luvas de 
procedimentos, óculos de proteção e avental sempre que houver a possibilidade de contato com fluido biológico. A lavagem das mãos antes e após calçar as luvas e no contato direto aos pacientes também é preconizada como forma de proteção ao trabalhador (Gomes et al.,2009).

Considera-se que o desenvolvimento de medidas institucionais que visem o treinamento e a informação relacionada à importância e ao uso correto dos EPls é primordial para a prevenção dos acidentes que envolvem exposição a fluido biológico. Por outro lado, o papel do trabalhador e sua conscientização relacionada a real necessidade da utilização de equipamentos de proteção é fundamental para a redução do número de acidentes de trabalho.

Em 1970, foi publicado pelo Center Disease Control and Prevention (CDC), organização internacional responsável pelo desenvolvimento de normas e condutas, equivalentes àquelas desempenhadas pela vigilância epidemiológica no Brasil, um manual técnico detalhado com orientações relacionadas às precauções a serem utilizadas em casos de isolamentos nos hospitais gerais. Uma revisão do manual foi apresentada em 1975, acrescentando a utilização dos equipamentos de proteção individual, recomendando o uso de máscaras, luvas e aventais de acordo com a categoria de isolamento (Centers for disease Control and Prevention,1970).

Em 1985 em decorrência da epidemia do vírus HIV, os CDCs publicaram novas diretrizes estabelecendo as chamadas precauções universais. Após relatos de que trabalhadores de saúde haviam se infectado com o vírus HIV, houve a necessidade de propor novas estratégias para a segurança do trabalhador (Benatti, Almeida, 2007).

Dessa maneira, foi necessário o desenvolvimento de medidas que incluíssem as precauções para infecções transmitidas pelo ar, gotículas e contato, a partir daí instituiu-se as chamadas precauções padrão que incorporaram as precauções universais e 0 isolamento para substâncias corporais. As precauções padrão aplicam-se a todas as situações em que 
houver a possibilidade de exposição do trabalhador aos fluidos biológicos. Recomendando o uso de óculos, máscaras, luvas e avental como barreira (Brasil, 2004).

Em 11 de Novembro de 2005 foi publicada pelo Ministério do Trabalho e emprego a norma regulamentadora número 32 que têm como objetivo principal estabelecer as diretrizes básicas para a implantação de medidas à segurança e a saúde dos trabalhadores dos serviços de saúde e daqueles que prestam serviços de assistência e promoção da saúde em geral (Brasil, 2005).

Na mesma direção a norma regulamentadora no 9 do Ministério do Trabalho e Emprego do Brasil estabelece a obrigatoriedade e implementação por meio dos empregadores do programa de prevenção de riscos ambientais, como forma de identificar os riscos aos quais o trabalhador está exposto, propondo medidas que visem a proteção da saúde (Brasil,1978).

Sendo assim, as empresas são obrigadas a fornecer os equipamentos de proteção individual de acordo com a atividade desenvolvida pelo trabalhador e compete ao Serviço Especializado em Engenharia de segurança e em Medicina do trabalho-SESMT, em acordo com a Comissão Interna de Prevenção de Acidentes-CIPA, recomendar ao empregador os equipamentos de proteção individual adequados de acordo com o programa de prevenção de riscos ambientais (Brasil, 1978).

Estudos demonstram que o uso de equipamentos de proteção individual por parte dos trabalhadores é influenciado por fatores individuais, organizacionais e outros relativos ao trabalho. Dessa forma, é necessário um suporte estrutural que favoreça a utilização desses equipamentos, como suprimentos em número adequado, orientações quanto ao seu uso, políticas institucionais que promovam a segurança do trabalhador, bem como o acompanhamento dos acidentados, incluindo a profilaxia após a exposição (Brevidelli, Cianciarullo, 2009). 
Nesse sentido, é importante destacar que a experiência adquirida e o tempo de atuação profissional tornam o trabalhador de enfermagem, alheio aos riscos aos quais está exposto no trabalho e o não reconhecimento das situações de vulnerabilidade agravam a problemática da ocorrência de acidentes e doenças relacionadas ao trabalho. Estudos evidenciam que somente após o acidente, é que o profissional começa a repensar seu modo de agir diante do trabalho, reconstruindo suas práticas (Maganini, Rocha, Ayres, 2011).

A seguir, apresento os procedimentos relacionados a assistência ao trabalhador que sofre acidente com fluido biológico, e as questões relevantes à notificação, profilaxia e monitoramento pós exposição.

\subsection{A assistência ao trabalhador acidentado com fluido biológico: notificação do acidente, profilaxia após a exposição e monitoramento do trabalhador}

Os acidentes de trabalho com fluidos biológicos devem ser tratados como emergência médica e as instituições devem colocar a disposição de seus trabalhadores protocolos de atendimento de notificação rápida, encaminhamento, aconselhamento, tratamento e acompanhamento pósexposição ocupacional.

O acompanhamento do trabalhador exposto é fundamental após a ocorrência do acidente tanto do ponto de vista clínico como sorológico. Há uma sequência de ações a serem realizadas após a exposição ocupacional a fluidos corporais. As lesões onde ocorre exposição de membranas mucosas ou rompimento da pele com penetração de agulha contendo sangue ou fluidos como sêmen, secreções vaginais, líquido cefalorraquidiano, sinoviais, líquido pleural, peritoneal, pericárdico e amniótico oferecem risco maior de contaminação ao trabalhador (Centers for disease Control and Prevention, 2001). 
Após a exposição aos fluidos biológicos recomenda-se que nos casos de exposição percutânea e cutânea a área exposta seja lavada com água corrente e em caso de contato com mucosas deve-se usar solução fisiológica (Brasil, 2004).

Nos casos de quimioprofilaxia para o HIV, a exposição deve ser avaliada quanto ao potencial para transmitir o vírus, o tipo de fluido biológico envolvido, via e gravidade da exposição, o conhecimento do paciente fonte e o resultado da sorologia para anti-hiv e por fim a situação clínica e imunológica do paciente fonte sabidamente infectado.

Os acidentes mais graves são aqueles que envolvem maior quantidade de sangue e em geral ocorrem através de lesões percutâneas bem como, onde o paciente fonte é sabidamente HIV positivo e possui número elevado de carga viral ou encontra-se em estágio avançado da doença. Recomenda-se que a quimioprofilaxia nos casos indicados deva ser iniciada nas primeiras horas após o acidente e no máximo em até 72 horas. A terapia tem duração de 28 dias (Centers for disease Control and Prevention,2001).

Nos casos em que a sorologia do paciente fonte é desconhecida a avaliação deve ser individual, novamente faz-se necessário avaliar o tipo de exposição e a probabilidade de infecção. Em casos de exposição ao vírus da hepatite $\mathrm{B}$, a vacinação anterior à exposição é a principal forma de prevenção, a resposta vacinal fica em torno de 90 a $95 \%$ em adultos sadios e deve ser realizada durante a admissão do funcionário na empresa e administrada a todos aqueles que tiverem contato com fluidos biológicos. $\mathrm{O}$ esquema vacinal é composto por três doses da vacina em intervalos regulares. Em alguns casos onde o trabalhador não é vacinado ou possui o esquema incompleto deve-se dar continuidade ou início ao esquema concomitante a administração de imunoglobulina (Centers for disease Control and Prevention, 2005; Brasil, 2004). 
A realização do teste sorológico para anticorpo superficial da Hepatite B (Anti- Hbs) indica a condição sorológica do trabalhador. Nos casos em que houve vacinação prévia é possível verificar a soroconversão da vacina e para trabalhadores não vacinados indica se houve imunização passiva durante o trabalho no ambiente hospitalar. Embora a realização do teste esteja associada a medidas pós-exposição, ressalta-se a realização do mesmo como forma preventiva, identificando a situação sorológica do trabalhador como forma de prevenir a Hepatite B (Pinheiro, Zeitoune, 2008).

Nas ocorrências relacionadas à Hepatite $C$ não há medidas profiláticas para a exposição ocupacional ao vírus portanto a única medida recomendada é evitar o acidente. É importante salientar a necessidade de realização dos testes sorológicos do paciente fonte para HIV, Hepatite B e C logo após a ocorrência do acidente. Nos caos onde o paciente fonte é desconhecido deve-se avaliar a probabilidade clínica e epidemiológica da ocorrência de contaminação como gravidade do acidente e prevalência da infecção no material de origem (Centers for disease Control and Prevention, 2001).

Tratando-se dos acidentes com fluidos biológicos, ainda faz-se necessário considerar as questões referentes à profilaxia pós-exposição e todas as dificuldades já apontadas na literatura para a não adesão ao tratamento (Sarquis, Felli, Mantovani et al.,2009). Estudos realizados no Brasil e em âmbito internacional evidenciaram que a maioria dos trabalhadores de enfermagem não realizou as medidas preconizadas após o acidente, como a correta notificação e os testes sorológicos pós- exposição. Nesse sentido, ressalta-se a importância de um sistema efetivo de vigilância aos profissionais acidentados (Bahadori, Sadigh, 2010; Damasceno et al., 2006).

As causas relacionadas ao não seguimento do tratamento profilático pelos trabalhadores de enfermagem pós-exposição estão associadas aos efeitos colaterais das drogas, a não conscientização, à falta de conhecimento sobre as condutas a serem realizadas após o acidente, e à falta de preparo 
emocional relacionada ao medo e angústia dos profissionais frente à possibilidade de adquirir HIV-AIDS (Vieira, Padilha, 2008).

Considerando a baixa adesão ao tratamento profilático em casos onde o trabalhador é exposto ao vírus HIV suscita questões que interferem na utilização dos antirretrovirais como o preconceito, o desconhecimento das medicações, os desagradáveis efeitos colaterais e a própria consciência do profissional acerca do fato de estar fazendo uso de uma medicação destinada ao tratamento de pacientes portadores do vírus HIV.

Em relação á notificação os acidentes de trabalho é necessário um protocolo de registro o qual deve conter informações relativas às condições do acidente (data e horário, avaliação do tipo e gravidade da lesão); informações do paciente-fonte bem como todos os dados do trabalhador de saúde. Todas as exposições ocupacionais devem ser comunicadas pela empresa por meio do preenchimento de formulário próprio denominado CAT- Comunicação de acidente de trabalho (Brasil, 1991). A partir de 2004 foi criada a rede sentinela de Notificação Compulsória de Acidentes e Doenças relacionadas ao trabalho. (Brasil, 2004).

A subnotificação dos acidentes de trabalho é fator preocupante no que concerne ao desenvolvimento de medidas de proteção a saúde do trabalhador. Quanto menos os acidentes são notificados, menos relevante socialmente torna-se a questão. É necessário que a força de trabalho faça com que suas situações de vulnerabilidade sejam expostas as autoridades competentes. A categoria profissional da enfermagem, não expõe suas reivindicações e cargas as quais está exposta ao prestar cuidados a população.

Em uma pesquisa realizada em um hospital do interior paulista verificou-se que do total de trabalhadores acidentados 37 (100\%), 34(91,9\%) referiram já terem deixado de notificar 0 acidente de trabalho. Entre as exposições não notificadas $34,4 \%$ foram ocasionadas por materiais 
perfurocortantes. Os autores apontam para a desproteção legal do trabalhador quando a ocorrência é subnotificada, ressaltando a importância de estudos que investiguem as dificuldades encontradas por parte dos trabalhadores na notificação desses acidentes (Napoleão, Robazzi, 2003).

Entre os motivos apontados para a subnotificação estão à falta de conhecimento sobre o risco de adquirir uma doença, dificuldades burocráticas no preenchimento dos sistemas, na avaliação médica dos trabalhadores, no preenchimento da CAT e dificuldades pessoais. Nesse mesmo estudo 32,70\% dos acidentados julgaram não ser necessária a notificação dos acidentes (Marziale, 2003).

A notificação dos acidentes é primordial para o desenvolvimento de estratégias de proteção à saúde do trabalhador, acompanhamento do estado de saúde e resguardo de seus direitos trabalhistas. Em uma pesquisa realizada em dois hospitais na cidade de Ribeirão Preto apontou que dos 336 acidentes relatados pelos trabalhadores do Hospital A, 243 (72,32\%) acidentes foram notificados e $93(27,68 \%)$ não notificados. No hospital B dos 35 acidentes, $21(60 \%)$ foram notificados e $14(40 \%)$ não notificados. Os resultados revelam que os trabalhadores de enfermagem possuem condutas diferentes diante da ocorrência de cada acidente. Dos 336 relatados pelos trabalhadores do Hospital A, 242 (72,02\%) acidentes foram ocasionados por material perfurocortante e desses, $150(61,98 \%)$ foram notificados e $92(38,02 \%)$ não. Dos 35 acidentes relatados pelos trabalhadores do Hospital B 30 (85,72\%) foram ocasionados por material perfurocortante desses, 18 (60,00\%) foram notificados e 12 (40,00\%) não (Marziale, 2003).

Estudo realizado em um Centro Cirúrgico de um Hospital em Belo Horizonte constatou que $84,6 \%$ dos acidentes ocorridos no período pesquisado não foram notificados. Uma das formas de diminuir a subnotificação é a informação acerca da importância dos registros, alertar o trabalhador para o risco de ter sido infectado e a necessidade de respaldo legal no caso de afastamento do trabalho (Oliveira, Gonçalves, 2010). 
Estudos apontam que a falta de padronização dos formulários utilizados para registro das exposições ocupacionais, a utilização de fluxos diferentes que dificulta a padronização do atendimento, a falta de registros de investigação dos acidentes, além da ausência do acompanhamento do desfecho das exposições contribuem para a não uniformidade das informações e dificuldades no atendimento dos trabalhadores (Silva et al.,2011).

Para que medidas de proteção à saúde do trabalhador sejam desenvolvidas é importante à existência de um sistema de notificação nas instituições de saúde e vigilância dos acidentes. Embora os acidentes favoreçam a exposição a vírus como Hepatite B, C e HIV estes acidentes algumas vezes produzem lesões pequenas nos casos de perfurações ou até mesmo não apresentam lesões em situações de respingos de secreções, o que favorece a subnotificação (Oliveira, Gonçalves, 2010).

No Chile entre os anos de 2003 a 2007, foi realizada uma experiência por meio da criação de um programa efetivo para manejo e vigilância dos acidentes biológicos entre estudantes da área da saúde na Universidade do Chile. O programa incluía assistência integral aos estudantes que sofreram acidente biológico durante as 24 horas após a ocorrência, além de testes sorológicos e entrega de antirretrovirais pós-exposição a fluido biológico infectado pelo HIV. A análise do estudo solidifica a importância de um sistema de monitorização dos acidentes de trabalho para a saúde da população bem como, indica os custos relativamente baixos para a implantação do programa diante dos benefícios. Partindo desta perspectiva os autores apontam como positiva a iniciativa para criação de programas similares em países em desenvolvimento (Fica et al., 2010).

As pesquisas evidenciam que o trabalhador após ter se acidentado com fluido biológico sofre alterações psicológicas e emocionais relacionadas à incerteza do diagnóstico do paciente e a falta de informações acerca de seu histórico de saúde. Somado a isso a espera dos testes sorológicos e a possibilidade de soro conversão acabam gerando angústias em relação à 
possibilidade de ter sido contaminado (Alves, Passos, Tocantins, 2009; Sarquis, Felli, 2009).

Dessa forma, é importante que os serviços disponham de uma assistência que garanta não apenas a orientação adequada aos trabalhadores que se vitimaram, como uma rede de apoio psicológico, minimizando o desgaste psíquico vivenciado por esses sujeitos.

Durante a assistência, o medo, a preocupação, indecisão, raiva, culpa são alguns dos sentimentos vivenciados pelo trabalhador após a exposição ocupacional. Diante de tantas dúvidas, torna-se urgente a reorganização institucional do processo de trabalho, a instrumentalização dos recursos humanos para o atendimento desses profissionais (Sarquis, Felli, 2009).

A partir das questões trazidas nesta breve revisão de literatura, é importante considerar que a ocorrência do acidente com fluido biológico ainda é um desafio no contexto de saúde do trabalhador de enfermagem que merece ser explorado sob diferentes aspectos, com vistas à redução da subnotificação, desenvolvimento de programas de monitoramento e assistência eficaz ao trabalhador de enfermagem.

Para melhor compreensão do fenômeno a ser desvelado, apresento no capítulo a seguir, o contexto do estudo tendo como pano de fundo a fenomenologia existencial de Martin Heidegger. 


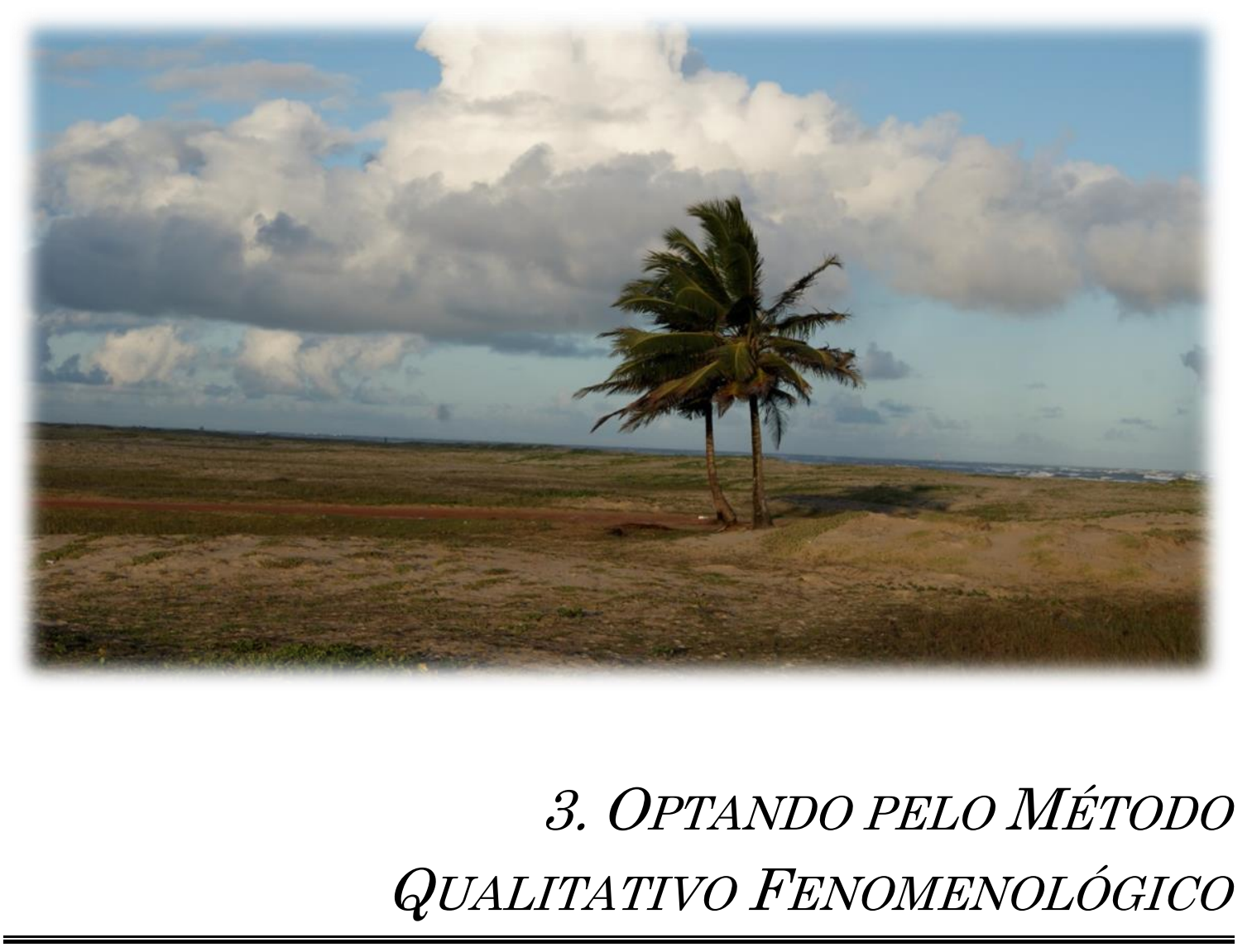


Neste estudo, optei pelo método qualitativo, considerando que o objetivo é compreender a experiência da assistência prestada aos trabalhadores de enfermagem que sofreram acidente com fluido biológico, resgatando as necessidades de cuidado por ele manifestas.

A escolha pela fenomenologia justifica-se por ser esta, uma vertente teórica que valoriza o ser em sua singularidade e busca compreender a experiência vivida pelo sujeito e das estruturas onde o fenômeno ocorre. No contexto dos acidentes de trabalho com fluidos biológicos acredito que abordar o fenômeno por meio da apreensão de sua essência é primordial uma vez que os fenômenos não podem ser compreendidos isolados dos sujeitos que os vive.

A fenomenologia é um método filosófico que busca através da compreensão de um fenômeno, desvelar o seu sentido para assim chegar àquilo que a coisa é (Heidegger, 2012).

O sentido de compreender, descrever e explicar as experiências vivenciadas pelo ser no cuidado ao outro contribui para o conhecimento de diversas dimensões que envolvem o cuidar. Desta forma, instrumentalizandonos podermos chegar às essências dos seres por meio do conhecimento do fenômeno, sugerindo mudanças nos processos de cuidado (Baptista, Merighi, Freitas, 2011; Duarte, Rocha, 2011; Diniz, Lopes, Silva, 2008).

Ao buscar compreender a experiência vivenciada pelos trabalhadores de enfermagem que sofreram acidente com fluido biológico, os significados ocultos nessa experiência, as necessidades de cuidado e lacunas no processo de assistência, optei pela fenomenologia existencial de Martin Heidegger, uma vez que este filósofo descreve as questões existenciais do ser inserido no mundo.

Heidegger (2012) se convenceu de que pensadores como ele deveriam voltar-se as experiências comuns que as pessoas tinham do mundo. Esta convicção o levou a escrever sua obra-prima "Ser e Tempo", que apresenta as questões relativas ao "SER". 
Heidegger procurou meditar sobre a diferença ontológica: ente é uma coisa, ser é o que permite que uma coisa seja a ideia é que o ser permite que algo seja e ente é a base material daquilo que é. A pedra é, A planta é, O rochedo é, Deus é, mas só o homem existe, as outras coisas estão. Ser é um problema humano. Ser é a questão do "é" (Werle,2003).

O filósofo então coloca um conceito importante que é o Dasein, ser-aí, onde o homem não é um sujeito muito menos um objeto, o homem é estar-aí. (Inwood, 2002). O trabalhador de enfermagem é um ser-aí pois está presente, existe, está disponível no mundo em contato com outros "entes" e que só existem a partir do momento que vivenciam experiências que os fazem repensar sua existência.

O ser-aí o Dasein, é um ser-no-mundo, pois está sempre situado em um contexto de vivência no mundo, há uma relação existencial com o mundo. Dessa forma, o trabalhador de enfermagem que se acidenta com fluido biológico é um ser-aí no mundo, que trabalha em um hospital, reside em sua casa, frequenta lugares no mundo. Outro conceito fundamental do ser-aí é o ser-com, para Heidegger o homem existe em um mundo compartilhado com os outros, ser-com é a forma como o ser sente, vive, se relaciona com as pessoas no mundo. Os trabalhadores de enfermagem imersos em sua existência se relacionam com os colegas de trabalho, com a chefia, familiares e amigos.

Nesse sentido, o mundo pode ser definido como aquilo a que dedicamos nosso cuidado e nós podemos ser definidos como aquilo que dedica cuidado ao mundo. $\mathrm{O}$ ser do homem só existe enquanto ser-no-tempo e o cuidado para Heidegger é compreendido como solicitude, preocupação, dedicação pelo outro (Stein, 2008).

Quando existe um relacionamento com o outro de uma maneira envolvente e significante dá-se a solicitude, constituída pela consideração, por tudo o que foi vivenciado e experenciado com o outro, pela paciência, algo que espero que possa vir a acontecer com o outro (Heidegger, 2012). 
O cuidado inautêntico com o outro reflete no seu autocuidado. Trabalhadores que possuem formas de cuidar onde não permitem ao outro se manifestar terão grandes obstáculos em demonstrar sua capacidade de autoconhecimento e cuidado com si próprio e em suas ações com aqueles que se relaciona. Apropriar-se de Heidegger para desvelar esta vivência torna possível repensar as necessidades de cuidado manifestas pelos trabalhadores de enfermagem acidentados, vislumbrando novos caminhos para a assistência à saúde do trabalhador.

Buscamos compreender por meio deste estudo como o ser humano vivencia suas experiências a partir da percepção de estar lançado no mundo. $O$ ser é humano, interrogação que é a nossa angústia, o fato que nós existimos. Consideramos que o problema do ser tem que partir do homem, interrogando o homem na sua existência, portanto, ser trabalhador de enfermagem e ter se acidentado com fluido biológico, constituindo-se este, um problema da existência.

Acredito na importância de compreender o fenômeno a partir do olhar dos sujeitos uma vez que se acidentar envolve uma proximidade com a finitude, medo da morte, da doença, e, portanto, é preciso fazer uma reflexão do homem de ser-no-mundo, a partir de Dasein que se refere a todo e qualquer ser humano e repensar a assistência prestada ao trabalhador acidentado com fluido biológico.

No próximo capítulo, apresento as etapas metodológicas que permitiram a realização da presente pesquisa. 


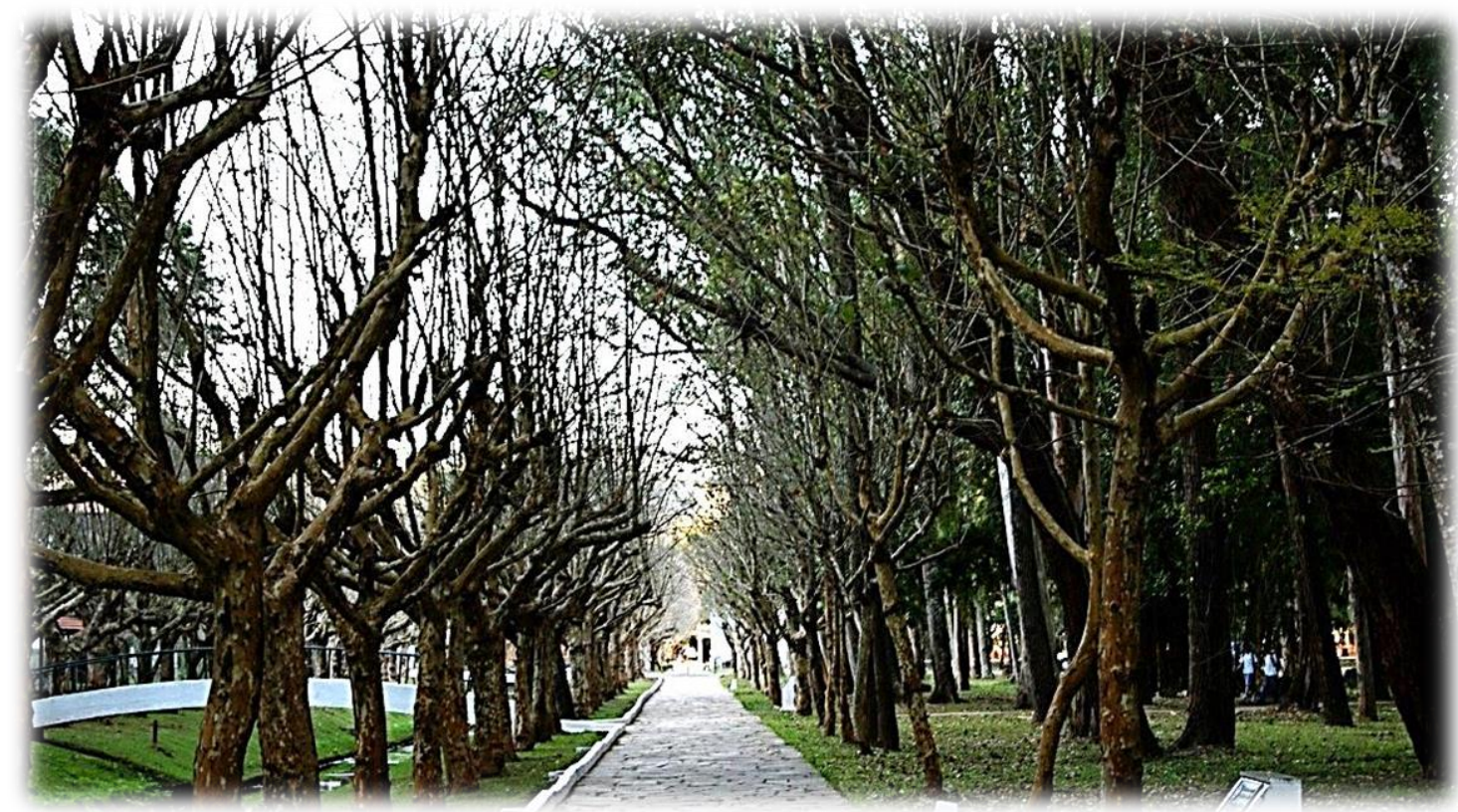

4. CAMINHO METODOLÓGICO 


\subsection{Tipo de pesquisa}

Trata-se de uma pesquisa qualitativa fenomenológica com abordagem da fenomenologia existencial de Martin Heidegger.

\subsection{Sujeitos da pesquisa}

Os sujeitos da pesquisa foram oito trabalhadoras de enfermagem que sofreram acidente de trabalho com fluido biológico. O único critério de inclusão para a seleção dos sujeitos foi ter sofrido acidente de trabalho com fluido biológico notificado conforme legislação vigente no Brasil até o período máximo de seis meses, respeitando o período de atendimento ao trabalhador preconizado no protocolo de atendimento ao acidente com fluido biológico.

Primeiramente, o Serviço Especializado em Engenharia de Segurança e em Medicina do Trabalho forneceu a listagem dos trabalhadores da equipe de enfermagem que sofreram acidente com fluido biológico nos últimos 6 meses. Na Listagem fornecida estavam relacionados 70 nomes de trabalhadores, mas apenas 29 nomes tinham informações como contato telefônico e setor de trabalho.

Desta forma, participaram da pesquisa oito trabalhadoras de enfermagem que estavam vivenciando o processo do acidente de trabalho com fluido biológico, sendo seis auxiliares de enfermagem e duas enfermeiras.

Primeiramente, realizei um primeiro contato onde foi possível esclarecer aos trabalhadores o objetivo do estudo e sua contribuição para a enfermagem. Em seguida partindo-se do aceite do trabalhador um encontro foi agendado de acordo com sua disponibilidade de data e local. A coleta de dados foi sendo realizada individualmente até o momento em que todas as minhas inquietações foram respondidas. 


\subsection{Região de inquérito}

A região de inquérito deste estudo foi constituída por trabalhadores da equipe de enfermagem que atuam em um hospital de ensino da região oeste de São Paulo e se acidentaram com fluido biológico. Para a coleta de dados não foi necessário definir um local, pois a região de inquérito era a própria situação em que o fenômeno estava ocorrendo, o mundo dos trabalhadores de enfermagem. Nesse sentido, não importava a unidade/ clínica, instituição de atuação do mesmo.

\subsection{Procedimento para coleta de dados}

As entrevistas tiveram a duração de aproximadamente 40 minutos, foram realizadas pela própria pesquisadora, entre os meses de Janeiro e Fevereiro de 2014 conforme disponibilidade dos trabalhadores e foram gravadas em aparelho de MP3 mediante sua autorização prévia a partir da seguinte questão norteadora e uma questão auxiliar: "Conte-me como foi para você ter se acidentado com fluido biológico?".

Questão auxiliar: "Como foi à assistência que você recebeu após o acidente?".

Foi utilizado um instrumento para caracterização sócio demográfica dos participantes da pesquisa (Apêndice 1).

\subsection{Aspectos Éticos}

O projeto foi submetido e aprovado pela Comissão de Ética em Pesquisa da Escola de Enfermagem da Universidade de São Paulo, Parecer no 464.028, de acordo com a resolução 466/2012 que regulamenta pesquisas em seres humanos no Brasil. 
Para cada entrevistado foi apresentado o Termo de Consentimento Livre e Esclarecido (TCLE) (Apêndice 2). Este documento fornece explicações sobre a pesquisa e assegura o sigilo das informações fornecidas. Foi resguardado ao entrevistado o direito de interromper a participação no projeto quando lhe fosse conveniente.

\subsection{O caminho para a Análise dos discursos}

Os discursos foram analisados seguindo as etapas do referencial de Josgrilberg (2000), onde por meio de uma sequência de etapas foi possível à compreensão do fenômeno.

Primeiramente, as entrevistas foram transcritas na íntegra, em seguida realizei a leitura e releitura dos depoimentos a fim de apreender as unidades significativas dos discursos. Em um segundo momento as unidades mais significativas foram agrupadas e identificadas a partir do referencial filosófico de Martin Heidegger, constituindo-se as unificações ontológicas, que serão discutidas adiante. 


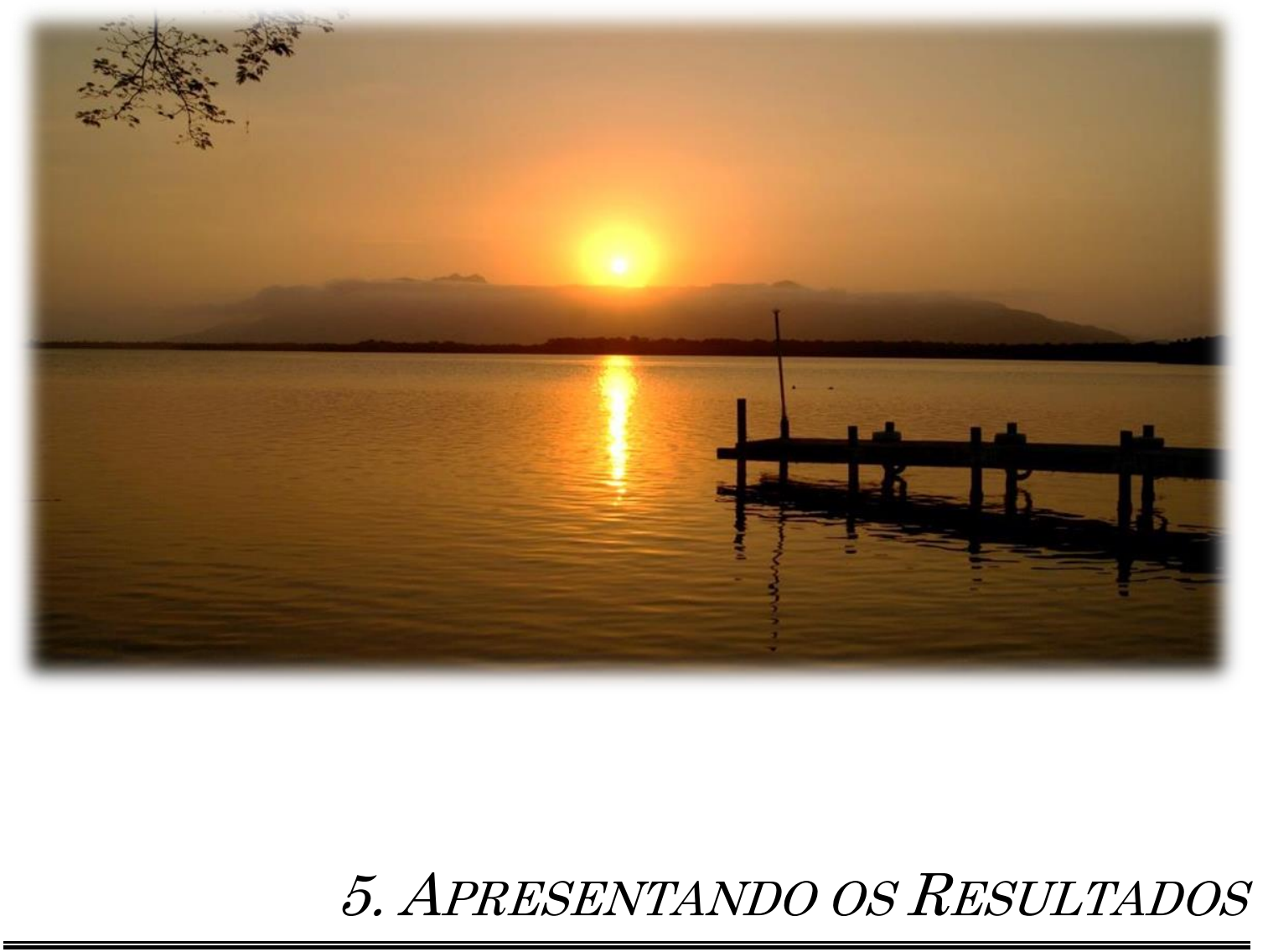




\subsection{Conhecendo as trabalhadoras de enfermagem que sofreram acidente com fluido biológico}

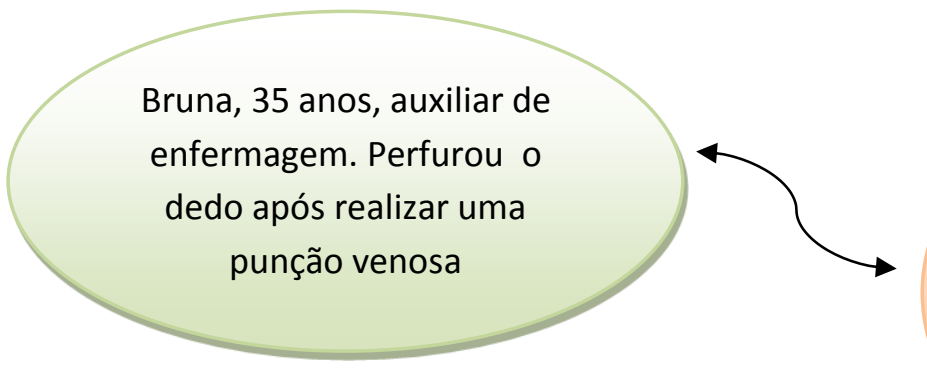

Joana, 50 anos, auxiliar de enfermagem. Perfurou o dedo ao descartar um escalpe na caixa coletora de perfurocortantes

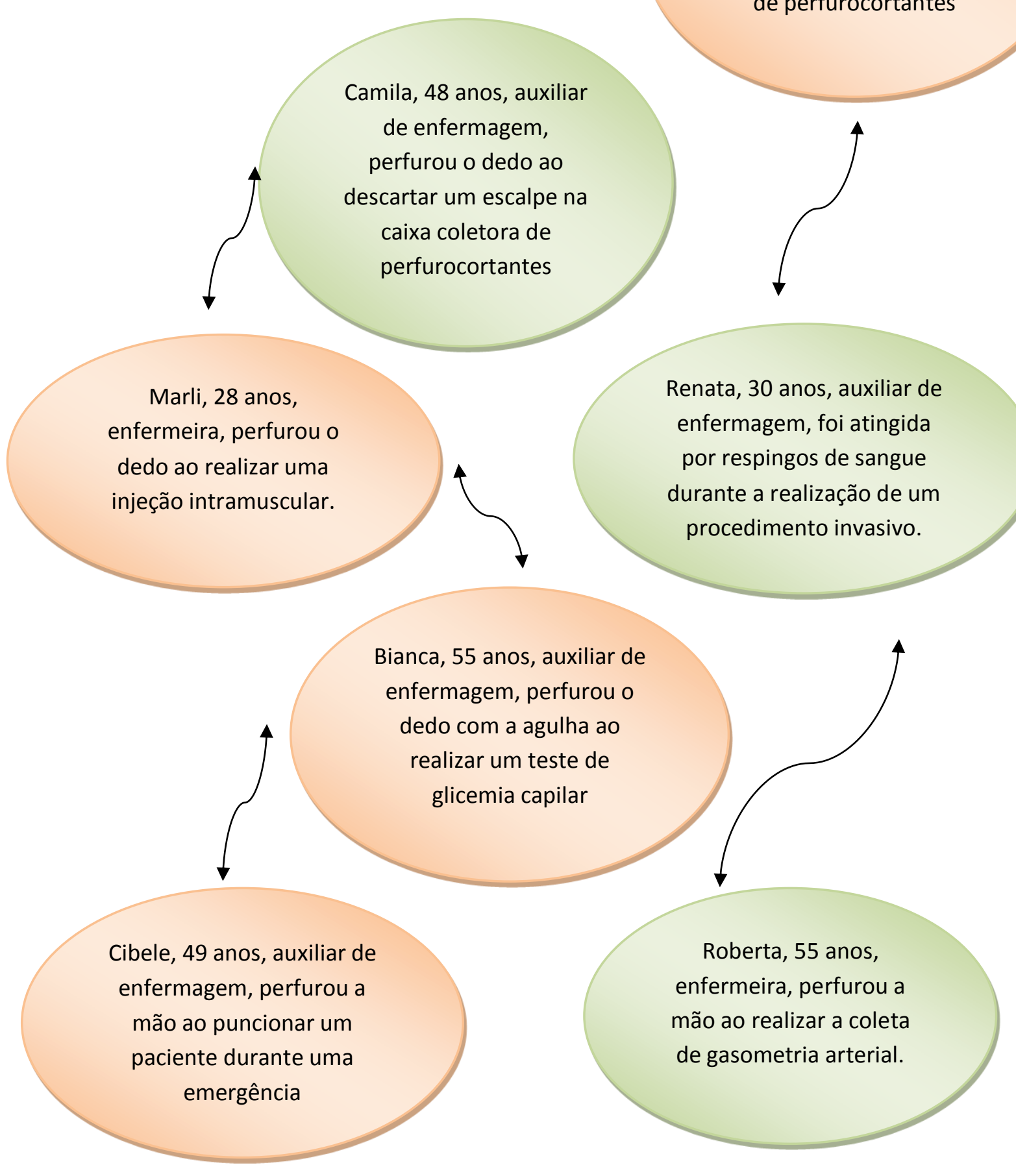




\subsection{Unificações Ontológicas}

A análise dos discursos permitiu a constituição de cinco unidades ontológicas segundo o referencial de Martin Heidegger que proporcionaram o desvelar do fenômeno, a experiência da assistência prestada aos trabalhadores de enfermagem que sofreram acidente com fluido biológico considerando suas necessidades de cuidado:

Ser no mundo vivenciando a acidente com fluido biológico.

* A angústia por ter se acidentado com fluido biológico.

- As necessidades manifestas pelas trabalhadoras de enfermagem após o acidente com fluido biológico: vivenciando o cuidado autêntico.

Vivenciando o cuidado inautêntico e a impessoalidade após o acidente de trabalho com fluido biológico.

* Superação e reorganização do trabalho por meio da transcendência.

\subsubsection{Ser no mundo vivenciando o acidente com fluido biológico}

Esta categoria traz as situações vivenciadas pelas trabalhadoras de enfermagem que favoreceram a ocorrência dos acidentes de trabalho envolvendo a exposição aos fluidos biológicos. Essas exposições foram decorrentes de vários fatores, entre eles o desconhecimento e mau uso dos instrumentos de trabalho como o descarte inadequado do material perfurocortante, e não utilização dos equipamentos de proteção individual.

As trabalhadoras reconhecem o desconhecimento acerca do funcionamento do dispositivo de punção endovenosa quanto à trava de segurança e o modo de manipulação do dispositivo identificando que a falta de conhecimento contribuiu para a o acidente. A narração a seguir demonstra essa realidade: 
Porque na verdade eu coloquei o jelco na bandeja e quando eu fui pegar o esparadrapo para fixar o acesso eu não vi o jelco, estava embaixo do esparadrapo aí espetou a ponta do meu dedo, eu já tinha puncionado, mas não sabia como que usava o jelco, era um jelco novo, não sabia como que manipulava porque na verdade eu nem conhecia, eles até tiveram treinamento só que no dia eu não estava então acabei não participando, não sabia que tinha aquela travinha, que você aperta depois que pega o acesso, então acabou acontecendo isso, mais por falta de conhecimento...(Bruna)

Os acidentes de trabalho também foram causados pelo descarte inadequado dos materiais perfurocortantes, os problemas neste descarte e fatores associados como o preenchimento da caixa coletora além do limite recomendado o que favoreceu a ocorrência desses acidentes. Os discursos seguintes refletem essa problemática:

Que nem a caixinha...tava a tampa eu acho que tava mal colocada, um negócio assim..na hora que eu joguei o escalpe lá dentro, voltou e furou meu dedo...(Joana)

Há algum tempo atrás né eu tava puncionando um paciente...tava colhendo sangue dele.. e quando eu fui..jogá o escalpe no perfuro..ele virou pra cima e picou o meu dedo...(Camila)

Foi o primeiro acidente de trabalho com material biológico, tinha feito uma IM (injeção intramuscular) num paciente e quando fui descartar me furei... (Marli)

As causas dos acidentes também se relacionam a utilização de materiais e instrumentos inadequados para a realização dos procedimentos contribuindo para a exposição das trabalhadoras, já que a técnica não é realizada corretamente, considerando que outro instrumento não padronizado 
para determinado procedimento é utilizado podem ocorrer falhas no processo de execução. O caso a seguir refere-se a uma trabalhadora que estava utilizando uma agulha ao invés de uma lanceta para a realização do teste de glicemia capilar:

Porque como não tinha lanceta eu estava furando com a agulha de insulina, aí ela (paciente) bateu, levantou a mão e a agulha voltou no meu dedo...(Bianca)

A não utilização dos equipamentos de proteção individual pelos trabalhadores durante a execução de procedimentos invasivos favorece a exposição do trabalhador aos fluidos biológicos, os relatos a seguir referem-se a trabalhadoras que não utilizavam equipamentos de proteção individual no momento dos acidentes e acabaram se contaminando com respingos de sangue e diurese:

Então ele tava passando um cateter central, quando ele foi tirar o sangue da seringa no campo, ele apertou com muita força 0 êmbolo da seringa então o sangue bateu no campo e subiu em mim ele colocou muita força no êmbolo da seringa..e eu sou pequenina... numa emergência querendo salvar a vida do paciente muitas vezes a gente acaba deixando de usar os epis..(Renata)

Da vez que eu me contaminei com líquido né... fui desprezar uma sonda e aquele líquido...a sonda caiu da minha mão..a sonda não o recipiciente, e voltou, eu me molhei toda com aquela secreção nojenta..ai foi horrível...(Joana)

Outro fator identificado como causador das exposições ocupacionais é a sobrecarga de trabalho vivenciada pelos trabalhadores de enfermagem nas instituições de saúde. Devido ao alto fluxo de pacientes e a alta demanda de serviços, a rapidez na execução nas atividades acarreta a diminuição da atenção no momento da realização dos procedimentos. A desatenção do 
colega de trabalho também foi um fator apontado pelos sujeitos. Esses fatores são descritos pela trabalhadora:

É. eu estava sozinha na sala de emergência, a sala estava muito cheia eu estava sozinha, aquela correria, chegou um paciente bem grave e eu fui puncionar, tinha acabado de furar o paciente, eu estava segurando o jelco e entrou na minha mão... Chegou um paciente né (...) estava cheio ele entrou na sala e já estava bem mal mesmo...(Joana)

A falta de atenção dos colegas de trabalho com as ações executadas pela equipe de enfermagem pode ocasionar acidentes, pois o outro acaba interferindo de forma negativa em um momento no qual a atenção do trabalhador deveria estar totalmente voltada para o procedimento que estava executando, mas interferências externas como os chamados verbais e até mesmo gestos físicos contribuem para as ocorrências. A trabalhadora abaixo descreve a situação em que o fator externo foi à causa de seu acidente de trabalho:

Então esse último acidente que eu sofri tinha uma paciente que estava na sala de agitação, era uma paciente psiquiátrica então eu falei, "olha vou dar uma picadinha no seu dedo pra fazer o dextro" Tá bom... aí o médico chegou, entrou na sala e foi conversar com ela, a paciente levantou a mão e furou meu dedo...(Bianca)

Aí dessa vez eu fui colher o exame do paciente...e na hora que eu fui por no tubo alguém me chamou e eu furei meu dedo...(Roberta)

E na hora que ele chegou (...). Eu estava puncionando o paciente, então o médico pegou e encostou na maca, então a maca andou e o jelco entrou na minha mão (..) poxa, a maca não é lugar pra apoiar e cruzar a perna, eu acho que a obrigação dele era ter me ajudado já que ele viu que o paciente estava ruim...(Joana) 
Sendo assim, por meio desta categoria percebe-se que durante o processo de trabalho da equipe de enfermagem, na execução das atividades e dos procedimentos, as trabalhadoras estão sob a influência de inúmeros fatores que podem contribuir para a ocorrência dos acidentes de trabalho com fluidos biológicos. A sobrecarga de trabalho, a escassez de pessoal, as demandas dos pacientes, além da ausência de treinamento são fatores importantes destacados pelas trabalhadoras.

\subsubsection{A angústia por ter se acidentado com fluido biológico}

Esta categoria aborda a angústia vivenciada pelas trabalhadoras após se acidentarem com fluido biológico, relacionada ao desespero, à possibilidade de adoecimento e ao medo da morte refletindo em uma sensação de iminente desamparo em relação àqueles que dependem de seu trabalho, seus filhos, irmãos e companheiros.

As trabalhadoras no momento do acidente passam a repensar suas vidas manifestando uma inquietude profunda, desespero e ansiedade que as oprime, sentem medo da morte e fragilidade diante da magnitude daquele acontecimento. A angústia caracterizada por uma mistura de sentimentos é evidenciada a seguir:

Não é uma angústia, preocupação, ansiedade é uma mistura, na hora você não consegue é.. separar o que que você tá sentindo...(Marli)

Fiquei muito desesperada na hora...O paciente estava internado (...) fiquei desesperadíssima, 3 dias aquilo não saia da minha cabeça um minuto...um minuto... (Camila)

Encostei na pia deu vontade de chorar, ...minha vontade era chorar..agora não sei que tipo de vírus ela tem e agora meu mundo acabou... depois de doze horas de plantão...ai foi horrível...(Renata) 
A angústia manifestada após a exposição aos fluidos biológicos surge em decorrência do medo de adoecer e também pelo sentimento de culpa inconsciente pelo acidente. Nesse sentido, as trabalhadoras vivenciam o sofrimento psíquico e o desprazer no processo de trabalho. Dessa forma elas passam a refletir sobre aquilo que é realmente importante no interior de sua existência e algumas trabalhadoras chegam a questionar o trabalho na profissão Enfermagem por acreditarem estarem arriscando as suas vidas.

Os discursos a seguir apresentam esse questionamento por parte das trabalhadoras:

Então eu fiquei muito, fiquei muito assustada na hora... nossa...fiquei muito chateada, chorei muito...porque eu fiquei pensando: poxa, aqui é meu local de trabalho, eu venho aqui para trabalhar e vem acontece uma coisa dessas...prejudica minha vida...(Bruna)

Eu tá aqui arriscando minha vida... nossa eu fiquei assim...eu chorei...chorei...chorei...muito (...) essa nossa profissão é muito ingrata..você corre o risco tanto de se acidentar, como de cometer erro... (Bruna)

Mas é muito ruim..a gente fica assim na hora a gente fica muito desesperada..a gente perde até o foco assim..a gente tá trabalhando pará tudo né...parou..(Camila)

A preocupação com as pessoas, a responsabilidade e o vínculo afetivo com filhos, esposos e irmãos geram um sentimento muito desesperador para as trabalhadoras principalmente quanto à possibilidade de contaminação. Os discursos evidenciam que muitas vezes, as trabalhadoras proporcionam o sustento da casa e o acidente significa o fim do trabalho, a perda da vitalidade. Esse sentimento angustiante manifesto pelas trabalhadoras é descrito como desesperador, podendo muitas vezes levar a quadros depressivos: 
Eu fiquei pensando poxa eu...aqui estou arriscando muito a minha vida..nossa..aí sei lá..e também pensei no meu filho...eu falei largar o meu filho em casa pra tá aqui arriscando minha vida...(Bruna)

Eu fiquei ali pensando...eu não tenho filho e agora sou uma portadora de alguma coisa..e agora chegar pro meu marido e falar sou portadora...isso já aconteceu com colegas...(Renata)

E como eu tenho uma irmã que é doente e depende muito de mim...ela tem esquizofrenia...e ela depende muito de $\operatorname{mim} . . .(B i a n c a)$

A incerteza em relação aos resultados dos exames, a possibilidade do tratamento com antirretrovirais e até mesmo a não efetividade desse tratamento medicamentoso após o acidente geram uma sensação de fraqueza, insegurança e fragilidade e está presente nas descrições das trabalhadoras a seguir:

Fui fazer o tratamento... tomei os 28 dias...Eu tomei aquele Kaledra...Nossa aquele remédio e o coquetel me deu uma diarreia, vômito...ai que coisa horrível...eu tive até que me afastar durante 14 dias do trabalho...Esse último foi horrível...porque a gente pensa...porque eu tenho que ficar tomando aquilo lá, não sabe se vai valer... se não vai valer ...(Bianca)

Começa aos pouquinhos...vai baixando a adrenalina da hora..e do momento..você fica pensando, ah.. será que estava contaminado? Será que vai dar positivo? Será que eu vou ter que tomar aquele monte de medicação...ai será que...ai será que...é muito difícil...(Marli)

As consequências do acidente para as trabalhadoras podem ser descritas como um sentir-se só, a solidão manifesta-se diante da incerteza e do 
enfrentamento daquele problema tão grave que é somente dela e de mais ninguém. A fala apresentada a seguir evidencia o sentimento de solidão:

Ultimamente eu estou meio assim, meio baqueada, eu acho que depois que a gente passa por esse problema de acidente às vezes a gente fica sozinha...(Bianca)

A exposição ocupacional manifesta nas trabalhadoras um repensar sobre sua própria vida e a possibilidade de adoecer devido à probabilidade de contaminação pelos vírus HIV, Hepatite $\mathrm{C}$ ou $\mathrm{B}$, traz a tona uma série de sentimentos relacionados à possibilidade da morte. Embora não pronunciado este sentimento está implícito na oratória das trabalhadoras:

Eu fiquei muito nervosa...porque ela era HIV..estava fazendo tratamento colhendo lícor todo dia.. estava com meningite...né...tinha tido uma meningite e já tratava há dois anos de HIV..aí fiquei muito...me deu uma depressão danada...(Bianca)

Na hora que você sofre aquele...aí você já pensa um monte de coisa né...poxa eu estou trabalhando, já pensou se eu contrair um HIV ou então se eu Hepatite C...não sei, aí você fica...eu fiquei...uns 3 dias assim preocupadíssima né...(Camila)

Acho que é uma angústia quando você vê que aconteceu isso...é que você começa a pensar, será que o paciente tinha uma doença infecto contagiosa, se vai ter que tomar antiretroviral...A gente fica com muito medo, medo mesmo de acontecer alguma coisa com você, se contaminar com fluido do paciente...(Marli)

Minha vida passou na minha frente no momento do acidente pensei, agora pode mudar minha vida ser portadora de um vírus $C$, de uma Aids... (Renata) 
Desta forma, compreende-se que as trabalhadoras após o acidente de trabalho vivenciam a angústia, um sentimento profundo que altera suas percepções acerca da sua vida e do seu trabalho. Assim, o acidentar-se não é apenas um problema institucional é antes de tudo uma vivencia própria de cada trabalhadora permeada por valores pessoais e questões muito subjetivas que resultam em estados de solidão, tristeza e depressão.

\subsubsection{As necessidades manifestas pelas trabalhadoras de enfermagem após 0 acidente com fluido biológico: vivenciando o cuidado autêntico.}

Nesta categoria, são descritas as necessidades de cuidado manifestas pelas trabalhadoras após o acidente, assim como os cuidados prestados pela instituição, o apoio da família, dos colegas de trabalho e da chefia, a importância do atendimento médico e o acompanhamento clínico e laboratorial após o acidente.

A trabalhadora de enfermagem após sofrer um acidente com fluido biológico necessita de apoio institucional, emocional e suporte para todas as ações que irá vivenciar, inclusive durante a realização de testes sorológicos, considerando que este momento é permeado pela angústia. Para a trabalhadora ter alguém para conversar, ser amparada e trazer de volta a sensação de segurança e estabilidade que a pouco perdera é muito importante. Os relatos abaixo evidenciam a importância desse cuidado:

Primeira coisa quando meu marido chegou.. eu falei assim..você não sabe o que aconteceu comigo hoje!!..e já comecei a chorar pra ele..comecei a chorar. ele falou assim calma mais o que aconteceu? Aí eu contei pra ele...não fica tranquila, não vai acontecer nada né e me tranquilizou ele pegou falou assim, não... mais isso daí. é um acidente de trabalho..você tem que estar preparada pra essas coisas..daí eu falei assim..mais a gente nunca tá preparada pra essas coisas...(Camila) 
A Clara foi uma das pessoas que mais me deu apoio...Clara esteve ao meu lado... Me deu tanto apoio que ela não foi embora enquanto as coisas não se resolviam...o pessoal também me deu respaldo, mas foram embora ...só que ela não foi embora, correu atrás das coisas ficou comigo até o fim do atendimento... Nessas horas é muito importante ter alguém ao seu lado...(Renata)

As trabalhadoras relataram como necessidade de cuidado o suporte da chefia após o ocorrido, demonstrando a importância do apoio emocional de outrem. O enfermeiro é a primeira pessoa a ser comunicada após a exposição, contribuindo para diminuir a ansiedade e o medo das trabalhadoras:

Então a Clarice que é minha chefe, já chamei ela...eu já comecei até a querer chorar...um desespero mesmo. Falei assim: Clarice pelo amor de Deus eu me piquei... E agora, e agora...? E ela tentou me tranquilizar, ficou do meu lado e disse assim: Não, tudo bem, vai ficar tudo bem...(Camila)

Eu precisava de alguém do meu lado naquele momento, então a Júlia enfermeira me pegou aqui fora, me colocou na outra sala $e$ falou: "Calma..." Eu falei, "calma, calma como?" Então ela conversou comigo, ficou do meu lado, me apoiando, sabe? Fez muita diferença para mim naquele momento ter alguém pra conversar...(Renata)

(...) A chefia tem me ajudado...(Bianca)

Outro cuidado apontado foi o atendimento médico após o acidente que significou para as trabalhadoras um momento de alívio e conforto, a segurança transmitida pelo profissional bem como o cuidado prestado possibilitou tranquilizá-las em relação as suas inquietações e quanto à possibilidade de terem sido contaminadas $O$ atendimento médico se faz importante para que sejam transmitidas ao trabalhador informações confiáveis 
partindo-se do princípio que a informação é uma necessidade de cuidado manifesta pela trabalhadora:

Assim a médica me deixou bem tranquila, quando viu que os exames da paciente tinham dado negativo ela falou assim para que eu não ficasse preocupada porque mesmo que tivesse algum problema, tinha um coquetel, que eu poderia tomar pro HIV...Aí eu fiquei mais tranquila, me deixou bem mais tranquila...(Bruna)

Eu procurei o médico, fiz o CAT (Comunicado de Acidente de Trabalho), passei pelo atendimento...ele pediu todos os exames tanto os meus como os do paciente, conversei bastante com 0 médico ele disse que a possibilidade de eu contrair alguma coisa era muito mínima...porque eu estava usando luva...ele prescreveu uns antirretrovirais por precaução, depois eu fiz todos os exames de novo... (Camila)

Eu fui ao médico que ele olhou lá que eu tinha colhido exame para o periódico há pouco tempo... o mês passado ele olhou lá...os meus exames não tinham dado hepatite nenhuma nunca tive contato com hepatite $A$, hep $B$ sou vacinada, hepatite $C$ não tenho então ele falou, está tudo bem com vc...só colhe do paciente e manda né...e me deu o papel...(Roberta)

O atendimento médico sob o olhar dos sujeitos é uma maneira de tranquilizá-las reduzindo a ansiedade relacionada ao medo de uma possível contaminação, a realização do teste rápido para o vírus HIV foi apontadA pela trabalhadora a seguir como um cuidado capaz de livrá-la do pesadelo momentâneo:

Hora que aconteceu o acidente ele (o médico) já pediu o exame de hiv que faz na hora, o teste rápido que sai em 5 minutos... E já pediu para coletar ali mesmo e deu negativo, então ele pediu pra eu repetir os exames... todos os exames deram negativo, foi um atendimento muito bom (...)(Renata) 
O acompanhamento clínico e laboratorial após o acidente, as conversas com o profissional capacitado e o respaldo institucional durante todo o processo proporcionam segurança e estabilidade para as trabalhadoras. Os discursos a seguir relatam essa realidade:

Eu vou lá no médico, passo na consulta, porque aqui eles acompanham a gente... pelo menos isso, eles acompanham aqui, para coletar os exames...(Camila)

Fiquei tranquila quando me falaram que.. estava tudo certo depois saiu todos os exames... fiquei mais tranquila, que já tinha encerrado o tratamento, tudo negativo..(Bruna)

O médico marcou consulta, pra voltar no retorno.. pra saber os exames.. quando eu vim no retorno ele falou, o paciente não tem nada.. e me deu alta..(Roberta)

Depois, eu fiquei aguardando e a doutora falou que tinha dado negativo, que o segundo teste de hiv e depois os outros exames deram negativo, passei com o médico e ele me deu alta...inclusive quando eu passei com médico depois de um mês o atendimento foi bom...(Renata)

A necessidade de atendimento psicológico aparece de maneira significante para uma trabalhadora e se faz necessária devido ao desequilíbrio causado pela vivencia do fenômeno, ter se acidentado com fluido biológico:

Na hora o que aconteceu abalou meu psicológico eu precisava de um apoio psicológico eu encostei assim na pia e comecei a lavar o meu rosto entendeu? Comecei a lavar o meu rosto... deveria ter no hospital uma psicóloga pra isso..porque na hora passa o mundo na sua frente...(Renata)

Portanto, esta categoria nos traz a relevância do apoio emocional neste momento tão delicado para as trabalhadoras de enfermagem, surge 
também à necessidade de apoio psicológico por meio de um profissional especializado, porém ela não é sanada. Outra questão identificada por meio desta categoria é a importância atribuída por elas ao atendimento médico e a toda a assistência prestada durante e após o acidente pela instituição, cuidados esses que as fizeram sentir-se mais seguras e confiantes em relação ao seu próprio cuidado.

\subsubsection{Vivenciando o cuidado inautêntico e a impessoalidade após o acidente de trabalho com fluido biológico}

A categoria apresentada a seguir relaciona-se às dificuldades enfrentadas após a exposição ocupacional e referem-se à impessoalidade manifesta pelos outros membros da equipe em relação ao colega acidentado, à atribuição da culpa pelo acidente e o ser mal visto pelos membros da equipe. $O$ cuidado inautêntico com a trabalhadora torna-se visível e se manifesta na falta de apoio.

As dificuldades assinaladas pelas trabalhadoras estão permeadas por questões burocráticas, ainda não resolvidas pelas instituições de saúde, como os problemas advindos da problemática para a efetivação da comunicação do acidente de trabalho. São apontada falhas no processo de atendimento, bem como o desconhecimento dos fluxos o que leva a não notificação por parte de algumas trabalhadoras.

Após o acidente as trabalhadoras vivenciaram o preconceito da equipe, sendo mal vista pelos outros em seu ambiente de trabalho. A impessoalidade é descrita pelas trabalhadoras como algo presente na vivência após 0 acidente com fluido biológico. $\mathrm{O}$ discurso das trabalhadoras representa a impessoalidade e a falta de apoio de alguns membros da equipe de saúde após a exposição ocupacional:

Você vai fazer o acidente de trabalho (cat.), eu acho que você é muito mal visto, as pessoas parece que ficam te julgando 
entendeu? Parece que você fez aquilo de propósito, que você se contaminou porque você quis... Ah é muito chato...(Joana)

No geral eu acho que, quando você sofre um acidente de trabalho as pessoas nunca veem que você sofreu aquele acidente porque ali teve uma coisa que fez acontecer...(Joana)

Só que.. sempre as pessoas quando veem assim sempre acham que você se contamino porque você quis...(Joana)

Para uma trabalhadora a falta de amparo e a indiferença dos outros membros da equipe de saúde presentes no momento do acidente fizeram com que ela se sentisse abandonada e desamparada:

Naquele momento eu me senti abandonada, abandonada... Ah sei lá, porque a enfermeira estava ocupada com os outros pacientes e tinha muitos pacientes graves, um paciente entubado... Aí chegou outro desacordado... E os dois médicos discutindo o caso em vez deles me darem um apoio... Ficaram discutindo o caso um virado pro outro... $E$ aí olha pra sua cara e tipo assim, se vire...(Cibele)

Outras questões manifestas pelas trabalhadoras foram as repercussões do acidente de trabalho para a sua vida profissional e aparecem nos discursos como o medo de perder o emprego. A demissão para elas estaria vinculada ao fato de que a culpa pelo acidente de trabalho é vista pela instituição como sendo da própria trabalhadora:

Com 3 anos aqui fiquei com medo de sei lá...correr o risco de ser mandada embora...(Camila)

Pra mim foi um pouco tenso...como já era o meu quarto acidente de trabalho, então eu fiquei pensando: Nossa, mais um pra minha coleção e aí tem aquele processo de...Ah...vou ser mandada 
embora, porque eles contam como procedimento ou técnica incorreta no seu prontuário do hospital...(Marli)

Outra adversidade assinalada é a burocracia envolvida no processo de abertura da comunicação de acidente de trabalho que favorece a subnotificação por parte dos trabalhadores que se acidentam. As instituições precisam repensar seus protocolos e fluxos facilitando o atendimento, tornando-o menos moroso e complicado para os trabalhadores. As falas das trabalhadoras demonstram as dificuldades em relação a esse processo:

Eu ainda fiz a metade do acidente de trabalho. Nossa... Nem fiz tudo porque é muita burocracia o acidente de trabalho...mais daí...fiz aquele monte de exame...Fui pra lá e pra cá, eram tantos papéis tantos lugares que nem fiz tudo...(Joana)

Até você conseguir fazer a CAT...é muito demorado aqui, você vai em vários lugares, é muito complicado, demorado, sabe?...É muito papel...(Camila)

Abri a cat porque fui obrigada, eu não queria abrir a cat...porque esse negócio de cat é muita burocracia você vai lá, vem pra cá... não sei o que... leva papel não sei aonde...você perde muito tempo...(...)vai pra lá vem pra cá... (...)É ruim isso daí. O Funcionário às vezes não faz a cat por causa disso pela burocracia que é...(Roberta)

Após o atendimento médico o protocolo indica a realização de exames laboratoriais no paciente fonte. As trabalhadoras de enfermagem relataram como dificuldade 0 fato de elas próprias terem que procurar 0 paciente fonte no espaço físico da instituição e o constrangimento muitas vezes relacionado ao fato da coleta de sorologias desse paciente, levando-as a situações embaraçosas frente aos próprios pacientes e seus familiares. Os relatos a seguir refletem essa realidade: 
Ah é..também teve a história do paciente.. O paciente já tinha saído daqui. Tinha ido lá pro terceiro andar, tive que ir lá no terceiro pra colher exame do paciente e a família não queria, foi aquela confusão... e eles disseram: "vai furar de novo?" Então eu expliquei para eles que eu tinha me furado então eles aceitaram de mau gosto...entendeu? (Joana)

Depois eu tive que colher o exame do paciente... tive que conversar com o paciente, que ele tinha que colher o exame, tinha que esperar, e o paciente querendo ir embora. Ele não ia ter que fazer nada só precisava colher mesmo os exames pra poder dar seguimento...eu fiquei assim sabe...sem graça...(Marli)

E o pior de tudo foi que o paciente foi a óbito..né..aí...foi um transtorno maior ainda...(Cibele)

Desta maneira, identifica-se que embora os acidentes de trabalho sejam situações recorrentes nos serviços de saúde, as instituições ainda não estão preparadas para atender o trabalhador que é exposto aos fluidos biológicos. Esta categoria revela problemas no fluxo de atendimento e notificação destes acidentes e a manifestação do preconceito e indiferença manifestos pelos próprios colegas de trabalho e membros da equipe de saúde, tornando evidente o cuidado inautêntico dirigido aos trabalhadores de enfermagem.

\subsubsection{Superação e reorganização do trabalho por meio da transcendência}

Esta categoria representa a superação das trabalhadoras após a exposição ocupacional relatando a reorganização do processo de trabalho e o repensar suas práticas cotidianas após o término do acompanhamento médico. 
As trabalhadoras de enfermagem após o acidente reconhecem que vivenciaram uma situação de instabilidade e vulnerabilidade, mas reconhecem a possibilidade de seguir adiante após os resultados negativos dos testes sorológicos e a sensação de alívio por não terem sido contaminadas:

Agora posso seguir minha vida mais aliviada, continuar trabalhando...(Roberta)

Graças a Deus que deu tudo bem...não aconteceu nada... (Joana)

Dessa forma, as trabalhadoras passam a identificar as situações de instabilidade em seu ambiente laboral reconstruindo suas práticas cotidianas, solicitando ajuda aos colegas e sinalizando para a chefia quando percebem uma situação de risco:

Agora quando está muito pesado ou tem um paciente difícil eu peço ajuda pros meus colegas, pra não me arriscar...(Bianca)

Fico com receio de sofrer um novo acidente sei lá e ter que passar por tudo de novo, fazer o cat, esperar o resultado dos exames...toda aquela preocupação. Conversei com a chefia sobre o acidente, falei que tínhamos que ter mais treinamentos, que os pacientes deveriam ser redistribuídos para que não ficasse mais tão pesado pra ninguém...(Roberta)

Ao identificar os riscos aos quais estão expostas as trabalhadoras conseguem recriar novas possibilidades para o desenvolvimento de suas atividades e percebem que mesmo após o acidente conseguem retornar ao trabalho ainda realizando o acompanhamento médico:

Mas graças a Deus deu tudo certo, tomei os 28 dias... Estou fazendo os exames ainda, falta mais um, mas tá tudo em ordem...tá dando pra trabalhar... (Bianca) 
Fiz o CAT, tudo certinho e..graças a Deus não deu nada até o presente momento meus exames é zerado..(Camila)

Nesse processo de retorno com o término do monitoramento, o fim dos exames sorológicos e o recebimento da alta médica, as trabalhadoras passam por um processo de mudança e sentem-se responsáveis pelo seu autocuidado durante a realização de suas atividades no trabalho. Na reinserção no trabalho após a exposição, as trabalhadoras assumem novas ações como forma de minimizar a ocorrência de novos acidentes.

Acho que agora estou bem mais tranquila, agora que os exames deram negativo eu estou indo trabalhar sossegada...Depois do acidente estou tentando prestar mais atenção nas coisas que eu faço sabe? Tomar mais cuidado com as coisas, pra não me perfurar de novo...ah, agora eu procuro me informar sobre os jelcos novos...(Bruna)

A gente toma mais cuidado..né..porque eu tenho muito medo de passar por tudo aquilo de novo...aquela sensação de medo de poder se contaminar, não quero passar por isso de novo......agora eu presto mais atenção na hora de realizar os procedimentos, porque eu tive a chance de viver de novo...(Marli)

Foi bom depois que eu passei com o médico no final do tratamento ele viu os meus exames e deu alta, agora estou mais sossegada, posso seguir a vida..mas acho que a gente tem que tomar cuidado.. Depois do acidente eu comecei a perceber os perigos, a prestar mais atenção nas coisas sabe? (Cibele)

Outra forma de superação do acidente relaciona-se a busca por tratamentos alternativos, em especial para esta trabalhadora, que procurou tratamento psicológico para o enfrentamento do acidente para que assim conseguisse reconstruir seu mundo vida: 
Eu acabei fazendo um acompanhamento psicológico na época do acidente porque fiquei muito abalada, mas agora estou melhor, consegui superar aquele medo...(Renata)

Portanto, após vivenciarem a exposição ocupacional as trabalhadoras de enfermagem buscam dar novo significado ao seu trabalho por meio do autocuidado, e passam a adotar novas práticas modificando assim elementos importantes no processo de trabalho que podem contribuir para a diminuição dos acidentes. 


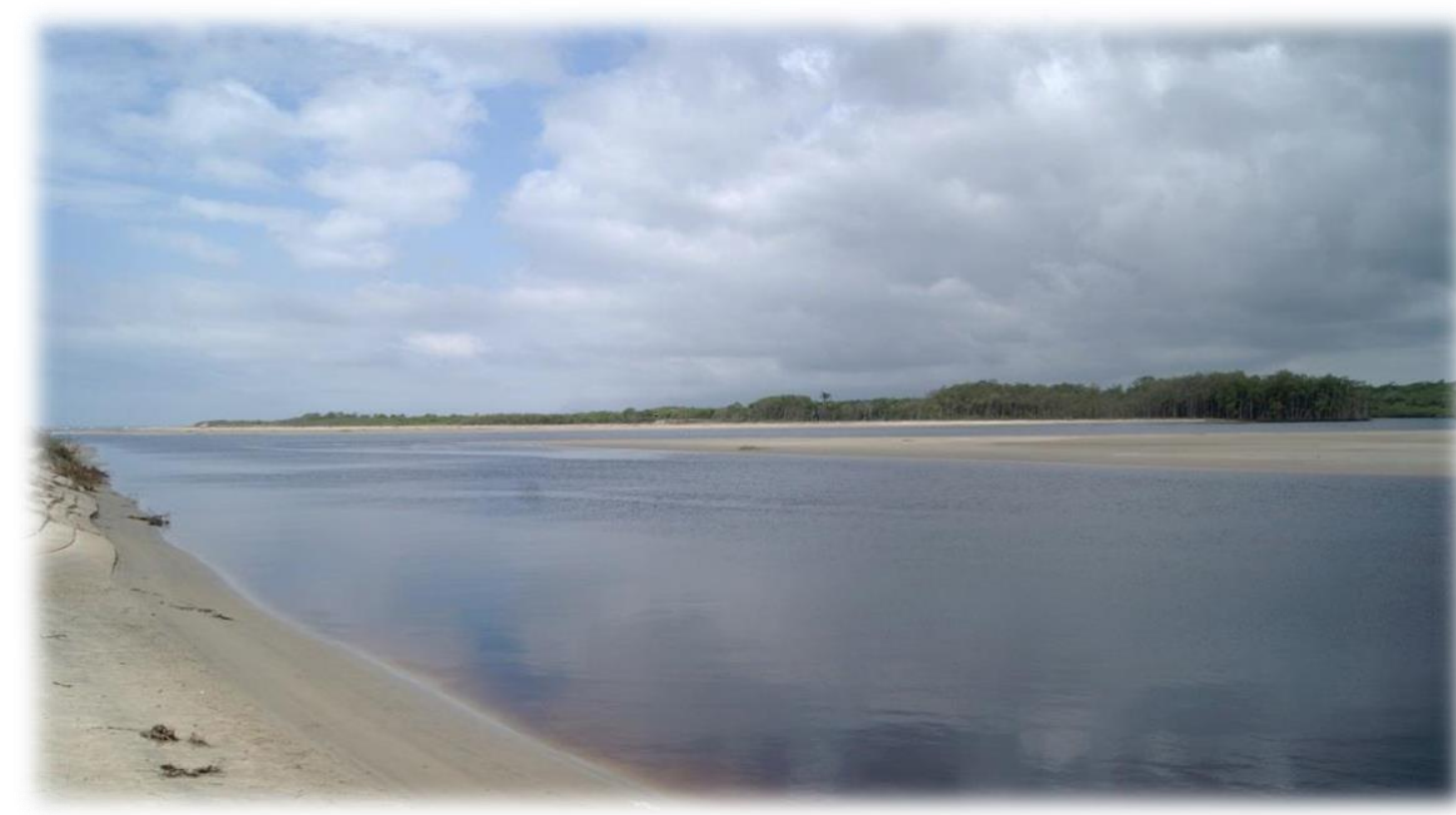

6. DISCUSSÃO 
Os discursos coletados possibilitaram a construção das categorias: Ser no mundo vivenciando o acidente com fluido biológico, $A$ angústia por ter se acidentado com fluido biológico, As necessidades manifestas pelas trabalhadoras de enfermagem após 0 acidente com fluido biológico: vivenciando o cuidado autêntico, Vivenciando o cuidado inautêntico e a impessoalidade após o acidente de trabalho com fluido biológico e a Superação e reorganização do trabalho por meio da transcendência, as quais descrevem a trajetória vivenciada pelas trabalhadoras de enfermagem após a exposição ao fluido biológico, incluindo o momento da ocorrência do acidente e os fatores envolvidos, os sentimentos experienciados, o cuidado e descuidado recebidos e a transcendência por meio da reorganização do trabalho.

Nesse aspecto observou-se que os acidentes ocorrem devido ao desconhecimento e mau uso dos instrumentos de trabalho como o descarte inadequado do material perfurocortante, não utilização dos equipamentos de proteção individual, sobrecarga de trabalho e falta de atenção dos colegas de trabalho.

Partindo da perspectiva heideggeriana o próprio homem é denominado de ser-aí Dasein, é um ente que só existe nesse mundo a partir das relações que estabelece com outros entes. Nesta perspectiva, as trabalhadoras de enfermagem são ser-aí, pois estão presentes, disponíveis e existem. O ser-aí imerso em sua existência é um ser que se encontra sempre situado num contexto de vivência no mundo (Heidegger, 2012).

Sendo assim, o homem é considerado estar-aí, o homem existe e só existe quando está envolvido em uma situação, portanto não existe fora do mundo (Heidegger, 2012). Dessa forma, as trabalhadoras de enfermagem são ser-aí, que estão no mundo em contato com outros entes e que só existem a partir do momento em que vivenciam experiências que as fazem repensar sua existência. A trabalhadora é Dasein porque está aí no mundo, ou seja, pensa, vive e sente. 
Portanto, conhecer as causas destes acidentes é imprescindível para o desenvolvimento das medidas de prevenção. No presente estudo entre as causas dos acidentes relatadas pelas trabalhadoras está à sobrecarga de atividades associada ao desgaste físico e mental.

Outros fatores, como a não utilização de Equipamentos de proteção individual (EPI), pouca experiência profissional e a maior rapidez na execução dos procedimentos devido à alta demanda de trabalho tornam os trabalhadores ainda mais susceptíveis à exposição ocupacional (Simão et al.,2010).

Uma pesquisa realizada revelou a distribuição dos acidentes de trabalho com exposição a material biológico entre trabalhadores de um hospital escola e identificou que, do total de 55 acidentes registrados as causas estavam relacionadas em ordem decrescente a falta de atenção do colega de trabalho 8 (14,3\%); Pressa e não utilização do EPI 7 (12,5\%), falta de atenção $6(10,7 \%)$; material inadequado $5(8,9 \%)$; movimento do paciente $4(7,1 \%)$ e recipiente de descarte cheio $2(3,6 \%)$ (Marziale et al.,2014).

Em relação ao descarte inadequado dos materiais, um estudo realizado em 50 municípios do sul do Estado de Minas Gerais identificou a ocorrência de 460 acidentes no período de 2007-2011 e verificou que a metade deles ocorreu entre auxiliares e técnicos de enfermagem e o descarte inadequado de material perfurocortante em sacos de lixo, bancadas, camas entre outros, correspondeu a $29,7 \%$ do total de acidentes, a ruptura da integridade da pele durante a administração de medicação endovenosa correspondeu a $8 \%$ dos casos (Julio, Filardi, Marziale, 2014).

Na mesma perspectiva, outros estudos também demonstram que 0 descarte inadequado de materiais pode estar relacionado à estrutura física das unidades de saúde, indicando estrutura inadequada. Segundo os autores, uma estrutura ruim pode favorecer o descare inadequado, favorecendo o acidente. Outros fatores como condições, organização e processo de trabalho hospitalar, a deficiente supervisão dos enfermeiros e inadequação do planejamento dos 
procedimentos são fatores que contribuem para o aumento das exposições ocupacionais a fluidos biológicos (Simão et al.,2010).

$\mathrm{Na}$ presente pesquisa também se observou como causas de acidente, os respingos em membranas mucosas.

Um estudo realizado no Irã que analisou os dados referentes a 171 exposições apontou que 32 (19\%) tiveram contato da mucosa com fluidos potencialmente infecciosos (Naderi et al.,2012).

Além disso, percebe-se que a escassez de recursos humanos pode ser apontada como a principal causa do ritmo de trabalho acelerado e nesta dinâmica de trabalho, situações de prestação de cuidado a adultos pouco cooperativos e crianças agitadas requerem abordagem especial, durante os procedimentos invasivos. O trabalhador necessita de mais atenção e a ajuda de um colega de trabalho, da família ou algum conhecido do paciente que possa acalmá-lo. Os equipamentos de proteção individual como as luvas reforçam a segurança durante a execução desses procedimentos (Lubenow et al., 2012).

Os trabalhadores muitas vezes tem consciência das causas dos acidentes e de como se prevenir, entretanto demonstram através de suas atitudes não ver os perigos à sua frente. Isso ocorre principalmente devido a rapidez na execução das tarefas e a falta de concentração nas atividades que estão realizando. A exposição ocupacional muitas vezes ocorre porque os trabalhadores não relacionam as suas ações a um risco potencial (Gusmão, Oliveira, Gama, 2013).

O planejamento das atividades assistenciais requer além do conhecimento técnico científico a capacidade para identificar a complexidade da assistência prestada e as situações de risco (Magagnini, Rocha, Ayres, 2011).

Como prática preventiva, a instituição de saúde deve proporcionar treinamento adequado a todos os trabalhadores. As ações de orientação e 
programas de treinamento que compõem a educação permanente devem estar presentes na prática diária do enfermeiro. Sendo assim, faz- se necessário o investimento na capacitação dos trabalhadores, e a supervisão de suas práticas de acordo com as normas já padronizadas (Soares et al.,2013).

Sendo assim, é sabido que a capacitação contínua relacionada ao manuseio e descarte de material perfurocortante na prática assistencial da equipe de enfermagem pode minimizar a ocorrência de acidentes entre os trabalhadores (Loureiro et al., 2009).

Estudos internacionais também ressaltam a importância da educação permanente. Pesquisa realizada na Holanda aponta para a existência de 13.000 a 15.000 acidentes de trabalho ao ano no país e refere à importância da prevenção e do manejo adequado dos acidentes. Para os autores a prevenção das exposições ocupacionais se dá através da educação permanente, organização do trabalho e uso de equipamentos mais seguros. $O$ desenvolvimento de ações visando à diminuição da ansiedade e incerteza por parte dos trabalhadores é apontado pelos autores como uma ação importante (vanWijk et al.,2010).

Durante a execução de suas atividades o trabalhador está exposto a cargas de trabalho que podem gerar processos de desgaste. $\mathrm{O}$ acidente com fluido biológico pode potencializar essas cargas principalmente a carga psíquica devido às repercussões pessoais, profissionais e sociais que o trabalhador vivencia após a exposição ocupacional (Magagnini, Rocha, Ayres, 2011).

Os discursos evidenciam o medo da finitude, caraterizado pela angústia das trabalhadoras de enfermagem. Segundo Heidegger (2012), a angústia pode ser definida como um modo de ser no mundo. É a angústia que provê o caminho mais fácil para a autenticidade, é um tipo de náusea ontológica que se apodera do ser-aí sempre que chegamos perto de compreender a instabilidade inerente de nossa existência. 
Dessa forma, tomadas pela angústia, as trabalhadoras apontam para a incerteza relacionada aos resultados dos exames e quanto à eficácia do tratamento com medicamentos antirretrovirais.

Um estudo realizado que utilizou o grupo focal para conhecer as repercussões dos acidentes com perfurocortantes entre trabalhadores de enfermagem identificou que a angústia é um sentimento manifestado por estes e apontada pelos autores como uma repercussão desfavorável para a saúde do trabalhador repercutindo de forma negativa em sua subjetividade, devido principalmente a espera dos resultados dos exames após a exposição (Castro,Farias, 2009).

A Angústia vivenciada por essas mulheres reflete a insegurança em relação ao seu futuro e as consequências desse fato para seus filhos e demais pessoas que estão sob seu cuidado ou responsabilidade.

Nesse sentido, estudos revelam que após a exposição ao fluido biológico, o trabalhador vivencia sentimentos que envolvem seus familiares, superiores e as pessoas com as quais convive, expressando sentimentos associados com as consequências do acidente para si e para aqueles que fazem parte da sua vida, alterando sua dinâmica familiar o convívio social e sua integridade moral. (Sarquis, Felli, 2009).

No que concerne à percepção dos trabalhadores em relação a essas consequências um estudo realizado em um hospital escola de grande porte, de uma cidade do interior de São Paulo demonstrou que os trabalhadores percebem-se vulneráveis a infecção por patógenos ou doenças após a exposição ocupacional e assim identificam possíveis danos á sua saúde decorrente desta infecção e até mesmo a progressão de uma doença crônica levando ao risco de infecções generalizadas e cutâneas e por último a infecção por uma doença que pode levá-los à morte (Malaguti et al.,2008). 
Após a ocorrência do acidente as trabalhadoras relataram como necessidade de cuidado o suporte da chefia e o apoio emocional dos colegas de trabalho.

Nesse aspecto, o despertar para o outro é a possibilidade de transcender em sua existência. As peculiaridades da existência como clarificação do ser podem ser todas capturadas, por uma única palavra: cuidado (Sorge). O mundo pode ser definido como aquilo a que dedicamos nosso cuidado, e nós podemos ser definidos como aquilo que dedica cuidado ao mundo, não podemos nos aproximar da autenticidade tentando ausentarnos do mundo, pois o cuidado revela nossa existência como sempre (Heidegger, 2012).

Assim a relação de cuidado consigo mesmo e com o mundo caracteriza todas as realizações da vida. A partir dessa projeção o homem passa a estar-com o outro em seu cotidiano e não mais solitário. Através da possibilidade de estar com o outro o ser-aí sente despertar um sentimento de solicitude por outrem, um preocupar-se com o outro (Heidegger, 2012).

A solicitude é estar-com o outro demonstrando cuidado e preocupação, é através do preocupar-se que o cuidado se manifesta transformando o homem para um existir além do que lhe foi posto. Essa é a manifestação mais autêntica da existência humana é transcender sua própria existência. Portanto, o cuidado é a totalidade das estruturas ontológicas do seraí no mundo, compreende todas as formas de estar-aí no mundo disponível, a todas as possibilidades junto com os outros. O cuidado pertence de forma essencial ao ser no mundo, o ser-aí nesse mundo é primordialmente preocupar-se com (Heidegger, 2012).

Deste modo, a figura do enfermeiro é a primeira a ser comunicada pela equipe de enfermagem após a exposição à material biológico. Tal fato demonstra o quanto é importante que o profissional enfermeiro conheça os protocolos e rotinas da instituição para que o trabalhador seja prontamente 
orientado e atendido. Também é sabido que o apoio de outrem como colegas de profissão contribui para diminuir a ansiedade e o medo das trabalhadoras (Neves et al.,2011).

A adesão ao monitoramento completo pelos trabalhadores de enfermagem que sofreram exposição ocupacional a fluidos biológicos ainda é uma problemática encontrada, entretanto os enfermeiros gerentes são responsáveis pela sua equipe tendo um papel relevante no monitoramento desse trabalhador no que se refere à exposição ocupacional em relação à prevenção, orientação quanto ao tratamento no que concerne ao uso de antirretrovirais já que é sabido que os trabalhadores muitas vezes abandonam o tratamento devido à presença de feitos colaterais (Claudio et al.,2013).

Esse apoio torna-se importante, pois desde o momento do acidente até $\mathrm{o}$ recebimento dos resultados dos exames sorológicos os trabalhadores passam por um desequilíbrio emocional em sua vida profissional e social.

Ao receber o cuidado autêntico por meio da preocupação é permitido que a trabalhadora de enfermagem se manifeste de forma integral durante 0 cuidado. O cuidado autêntico se dá quando eu permito ao outro se manifestar, demonstrar sua existência (Heidegger, 2012).O estar- com o profissional médico após o acidente de trabalho proporcionou a trabalhadora de enfermagem uma nova possibilidade para a existência, a possibilidade de não ter sido contaminada, de continuar vivendo de maneira plena.

Podemos cuidar do outro de forma autêntica e inautêntica. Para cuidarmos de maneira autêntica precisamos nos preocupar com o outro. A preocupação se comprova, pois como uma constituição ontológica da presença que está imbricada tanto com o seu ser para o mundo da ocupação quanto com o seu ser para consigo mesmo. O cuidado confere totalidade ao ser-aí, a identidade da trabalhadora é construída através da relação com as outras e na relação consigo mesma. Cuidar de forma autêntica é assumir-se livre a existência sem deixarmos de considerar nossas limitações. O cuidado pertence 
de forma essencial ao ser no mundo, o ser-aí nesse mundo é primordialmente preocupar-se com (Heidegger, 2012).

Desta maneira, considerando que a angústia relacionada ao acidente se estende durante todo o período de acompanhamento muitas vezes esse tempo é tão angustiante quanto à própria exposição. Infelizmente ainda há falhas institucionais no processo de assistência ao trabalhador após a exposição onde o mesmo muitas vezes não recebe assistência médica e nem psicológica por parte destas instituições (Araújo et al.,2012).

Outra necessidade de cuidado apontada pelas trabalhadoras foi a relevância do atendimento médico após a exposição a material biológico.

Os trabalhadores devem receber assistência médica conforme os procedimentos recomendados pelo Ministério da Saúde (Brasil,2006), entre as ações imediatas estão o cuidado com a área de exposição, a quimioprofilaxia para os vírus HIV e Hepatite B nos casos indicados, a solicitação de exames sorológicos, avaliação do paciente fonte e o acompanhamento clínico e laboratorial após a exposição.

Sendo assim, as condutas tomadas imediatamente após a exposição são necessárias para minimizar a possibilidade de soroconversão. É importante que o protocolo de atendimento seja claro para a trabalhadora, bem como oconhecimento dos passos a serem seguidos pelos trabalhadores de saúde pós-exposição biológica é de fundamental importância para que os exames e possível quimioprofilaxia sejam realizados o mais rápido possível, minimizando as chances de contaminação.

Outro procedimento recomendado após o acidente é a emissão da comunicação de acidente de trabalho e a notificação compulsória desse agravo de acordo com a Portaria no 777 (Brasil, 2004) essas ações resguardam às trabalhadoras seus direitos garantindo respaldo legal principalmente nos casos onde ocorre soroconversão. (Paiva, Siqueira, 2013) 
Portanto, o acompanhamento clínico e laboratorial após a exposição deverá ser realizado para todos os profissionais de saúde acidentados que tenham sido expostos a pacientes-fonte desconhecidos ou pacientes- fonte com infecção pelo HIV e/ou hepatites B e C, independente do uso de quimioprofilaxias ou imunizações, por no mínimo 6 meses a um ano, o que possibilita a prevenção de uma possível infecção (Brasil, 2006).

Para que a assistência seja realizada de maneira efetiva 0 trabalhador deve conhecer os seus direitos bem como o protocolo de encaminhamento da empresa após o acidente de trabalho. Isso evita a frustração do profissional relacionada à instituição de trabalho e previne contra mal-entendidos entre eles (Lubenow et al., 2012).

No decorrer da vivência por ter se acidentado com fluido biológico as trabalhadoras enfrentam dificuldades relacionadas ao preconceito pelo fato das outras pessoas acharem que 0 acidente se deu por incompetência do trabalhador, além de ter sido sentido por elas como incapacidade e incompetência.

As dificuldades enfrentadas pelas trabalhadoras de enfermagem refletem o cuidado inautêntico ou descuidado após a exposição ocupacional. 0 descuidado se relaciona a modos deficientes de solicitude e ocorre quando não é permitido ao outro se manifestar, este é deslocado de sua posição tornandose dependente e dominado mesmo que esse domínio seja silencioso e permaneça encoberto para o dominado (Heidegger, 2012).

Desta maneira, o preconceito da equipe de trabalho e a representação social que o profissional e o hospital possuem é a de que o trabalhador é sempre o culpado pelos acidentes. Essa crença provém de uma realidade previamente construída, ancorada em princípios conformistas. Os funcionários não refletem sobre o problema; apenas o aceitam como é (Araújo et al., 2012). 
Assim, é importante a reflexão sobre as causas dos acidentes e o olhar de que o trabalhador é somente parte de um processo, afastando a culpa, já que esta é uma visão reducionista, o motivo dos acidentes deve ser atribuído às influências ambientais e não somente ao processo de pensamento individual. É um problema com múltiplas causas e por isso os trabalhadores devem ser orientados de forma adequada para que se tornem cientes dos riscos inerentes ao seu trabalho e de que há formas de prevenção que não dependem apenas de suas ações (Lubenow et al.,2012).

As trabalhadoras também referem como enfrentamento o medo relacionado às ações da chefia e a possibilidade de perder o emprego após a exposição ocupacional.

Logo, concepções como estas decorrem muitas vezes de práticas punitivas de supervisão nas instituições e não educativas e acabam fazendo com que o trabalhador coloque em segundo plano a questão relacionada a um possível adoecimento decorrente do acidente (Malaguti-Toffano et al.,2012; Sarquis, Felli, 2009).

Esta crença das trabalhadoras reflete 0 desconhecimento relacionado aos seus direitos trabalhistas e a hierarquia presente nas instituições de saúde, através de relações de poder extremamente verticalizadas e mantidas através do autoritarismo.

Os acidentes com exposição a material biológico são de notificação compulsória podendo ser realizada em rede de serviços sentinela específica (Brasil, 2004). No presente estudo as trabalhadoras entrevistadas deixaram de notificar o acidente ou o fizeram pela metade descrevendo o processo de abertura da comunicação de acidente de trabalho como lento, burocrático e complicado.

Estudo realizado visando identificar a ocorrência e características dos acidentes do trabalho registrados no Sistema de Informação de Agravos de Notificação (SINAN) direcionadas ao Centro Regional de Saúde do Trabalhador 
(CEREST) de uma cidade do interior de São Paulo verificou que, o número de acidentes notificados é baixo se comparado ao número de trabalhadores expostos, os autores apontam que dada à importância da notificação dos acidentes para o desenvolvimento de estratégias preventivas é necessário à conscientização dos trabalhadores quanto à importância da notificação e o treinamento e capacitação dos profissionais para melhor preenchimento dos registros visando o aperfeiçoamento das informações contidas nos sistemas de informação (Valim, Marziale, 2012).

É importante ressaltar que esta problemática está presente em outros países, estudos internacionais apontam como causa das subnotificações dos acidentes de trabalho a insatisfação dos trabalhadores em relação às investigações dos acidentes após os relatos. Sendo assim, o aumento dos acidentes e a frequência de subnotificação é fator preocupante e indicam a importância da adoção de protocolos padronizados após a ocorrência de acidentes como forma de reduzir a subnotificação (Azadi, Anoosheh, Delpisheh, 2011; Quinn et al.,2009).

A fragilidade dos protocolos de atendimento ao trabalhador acidentado expressa 0 descuidado e a indiferença com o outro presente na cotidianidade do ser-aí e se reflete em atos de desatenção e impessoalidade, o impessoal que não é nada determinado, mas que todos são embora não como soma, prescreve o modo de ser da cotidianidade e o não preocupar-se pode levar a atos de negligência durante o cuidado.

A indiferença em relação aos acidentes e a inexistência de protocolos claros de atendimento reflete o ser por um outro, contra um outro, sem os outros, o passar ao lado um do outro, o não sentir-se tocado pelos outros. Esses modos caracterizam a convivência cotidiana e a medianidade um com outro, o não sentir-se tocado pelas trabalhadoras de enfermagem que se acidentaram com fluido biológico demonstra um modo deficiente de solicitude (Heidegger, 2012). 
Modos deficientes de solicitude relacionam-se a forma inautêntica de ser no mundo, desse modo o ser-aí vive de maneira coisificada. O não preocupar-se com o outro que sofre um acidente no trabalho faz parte de uma existência inautêntica (Heidegger, 2012).

Outro problema vivenciado pelas trabalhadoras foi à coleta de exames sorológicos do paciente fonte. Um Estudo que relacionou as razões documentadas para a não testagem do paciente fonte discorre que essa é uma questão preocupante. A pesquisa aponta que na maioria dos casos muitas vezes os pacientes não são testados devido à transferência de leitos entre as áreas do hospital, alta dos pacientes antes do teste, a notificação tardia, a não priorização dos testes das fontes e recusa por parte dos pacientes na realização do teste. Para os autores isso pode indicar fracasso do corpo clínico na solicitação dos exames e a necessidade de implantação de medidas para um problema tão complexo (Giri et al.,2013).

Esta problemática evidencia uma grave falha institucional no processo de atendimento ao trabalhador acidentado devido às dificuldades para realização ou a não realização dos testes sorológicos implicando em constrangimentos para as trabalhadoras e probabilidade de contaminação produto de um diagnóstico tardio do paciente fonte. Torna-se uma questão critica e preocupante nas instituições de saúde, pois reflete a banalização dos casos de exposição ocupacional aos fluidos biológicos.

Após o acidente com fluido biológico as trabalhadoras retornam ao ambiente laboral e entre às repercussões favoráveis ao seu comportamento destaca-se a reorganização do processo de trabalho através da adoção de medidas de precaução, cuidado e atenção na manipulação de fluidos biológicos durante a execução de procedimentos devido ao medo da recorrência de novos acidentes e a possibilidade de contaminação como consequência desse fato (Castro, Farias, 2009). 
A partir do momento em que o trabalhador percebe em seu processo de trabalho o risco de se acidentar devido às condições de trabalho inadequadas, a falta de esclarecimento sobre biossegurança e a sobrecarga de trabalho, eles passam a considerar a enfermagem uma profissão de alto risco tornando-os mais cautelosos em relação as suas atividades assistenciais (Araújo et al., 2012).

A identificação destes riscos também está vinculada neste estudo a angústia e as alterações psíquicas, emocionais, econômicas e na vida familiar. A consciência da gravidade do acidente gera posturas exigidas para alterações de modos no trabalho (Ribeiro et al., 2010).

Quando o trabalhador reconhece a seriedade da questão, as cargas a que estão expostos e sua responsabilidade individual no contexto da prevenção abre-se um novo caminho, um repensar as práticas cotidianas, esse repensar pode ocorrer através do envolvimento de todos os profissionais por meios de seminários, reuniões clínicas, programa de educação permanente que promovam a construção e adoção de novas estratégias para a prevenção dos acidentes (Oliveira, Gonçalves, 2010).

Desse modo, a reflexão acerca do acidente e a compreensão da importância do monitoramento biológico proporcionam a construção de ambientes saudáveis de trabalho mediante o reconhecimento e o cumprimento das normas de biossegurança durante a prestação da assistência de enfermagem e o cuidado com ele próprio tornando o risco de ocorrência de acidentes, baixo ou inexistente (Alves, Passos, Tocantins, 2009).

Assim, considera-se importante que os trabalhadores reconheçam seus direitos trabalhistas, o atendimento adequado e o respaldo para a tomada de decisões mesmo após a alta médica com o fim do monitoramento e a importância do retorno salutar ao trabalho, pois a satisfação no trabalho está diretamente relacionada à qualidade da assistência prestada (Gusmão, Oliveira, Gama, 2013). 
Posto isso, torna-se necessário o investimento das instituições de saúde em estratégias objetivando a prevenção dos acidentes com material biológico, sobretudo as exposições causadas pela manipulação de material perfurocortante, por se tratar da principal via de transmissão ocupacional do vírus HIV (Gomes et al.,2009).

Após a exposição ocupacional o ser-aí trabalhadora de enfermagem busca em suas diversas possibilidades no interior de sua existência um poder ser próprio da presença por ela mesma a partir do momento que ela se deixa encontrar. $\mathrm{O}$ encontro da presença deve permitir um ser-si-mesmo em sentido próprio o que determina o modo de existir da presença, o si-mesmo (Heidegger, 2012).

A superação do acidente de trabalho se dá quando a trabalhadora de enfermagem consegue modificar a sua existência passando do impessoal para o ser-si-mesmo em sentido próprio, ela o faz por meio de uma escolha, uma decisão por um poder ser a partir do seu próprio si-mesmo. É através dessa escolha que o Dasein torna possível para si mesmo o seu próprio poderser (Heidegger, 2012).

Por meio da transcendência a trabalhadora parte para novas possibilidades visando à adoção de práticas preventivas no ambiente laboral e a reconstrução de seu processo de trabalho. Desta forma, é possível que o seraí reconstrua seu mundo vida após o acidente superando o caminho da identidade, da essência em busca do ser próprio. 


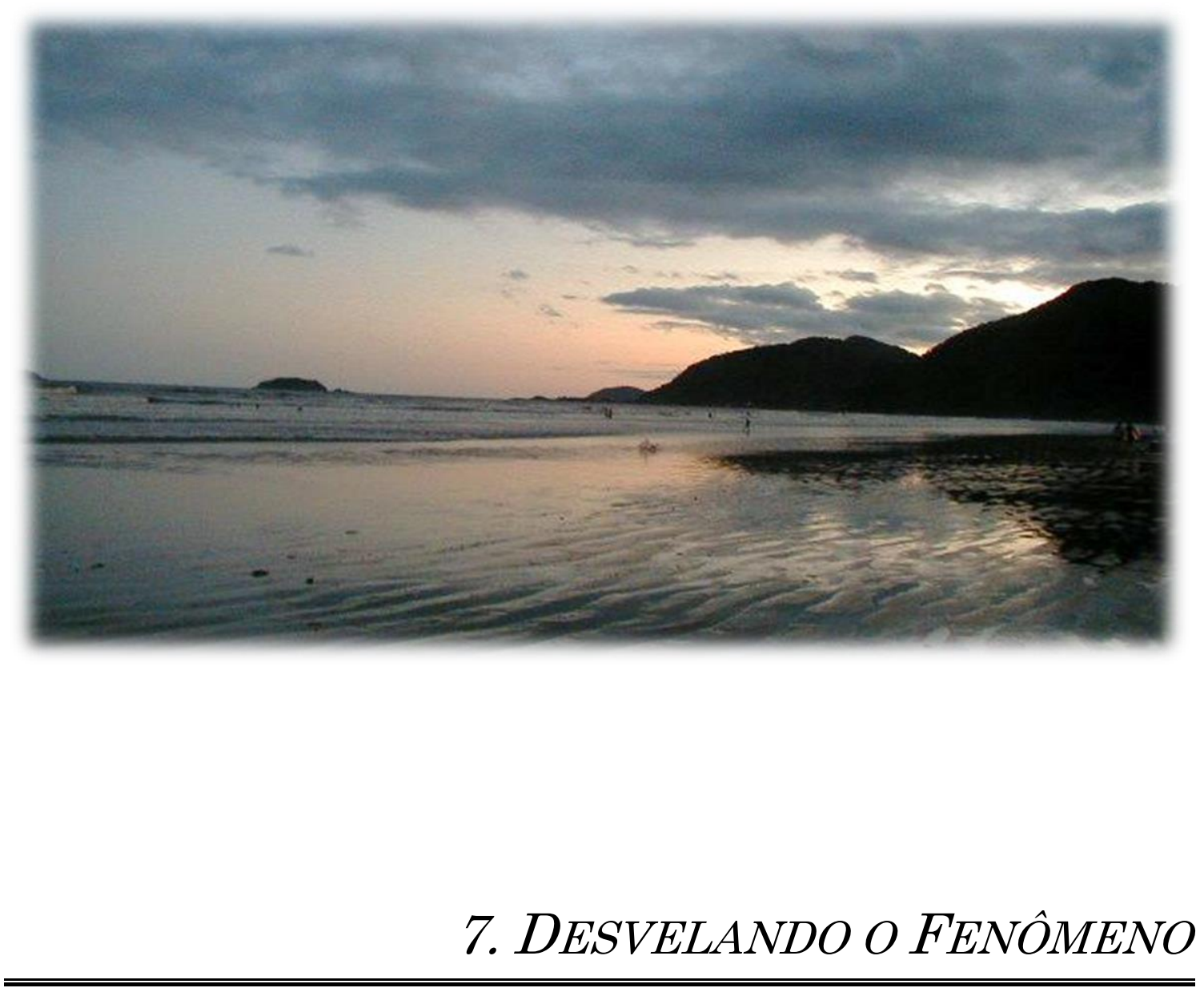


Após o acidente com fluido biológico, as trabalhadoras de enfermagem vivenciam a angústia associada ao medo de adoecer e perceber a finitude. Observa-se a preocupação com os filhos, com irmãos, esposos e todas as pessoas que estão sob sua responsabilidade. Ao vivenciar a angústia, as trabalhadoras fazem uma reflexão e começam a questionar o trabalho na enfermagem, descrevendo-o como ameaçador e como um risco à sua própria existência.

Nesse momento tão delicado, o apoio emocional dos colegas de trabalho, membros da equipe de saúde e da própria chefia foram apontados pelas trabalhadoras como a manifestação de um cuidado autêntico e que permite ao ser-aí manifestar-se. $\mathrm{O}$ atendimento psicológico por um profissional especializado surge como necessidade de cuidado e torna-se importante partindo-se do pressuposto que muitos trabalhadores sofrem desgaste psíquico após a exposição ocupacional.

O atendimento médico sob o olhar dos sujeitos é uma maneira de tranquilizá-las reduzindo a ansiedade relacionada ao medo de uma possível contaminação, assim como a realização do teste rápido para o vírus HIV ser apontado como uma necessidade e um cuidado capaz de livrá-las do pesadelo momentâneo.

O acompanhamento clínico e laboratorial após o acidente e o respaldo institucional durante todo o processo, traz segurança as trabalhadoras tornando-as possuidoras de seu próprio cuidado.

Quanto às dificuldades relacionadas à exposição ocupacional elas estão relacionadas à impessoalidade manifesta pelos outros membros da equipe em relação ao colega acidentado após o acidente, a atribuição da culpa pelo acidente e o ser mal visto pelos membros da equipe. O cuidado inautêntico com a trabalhadora torna-se visível e se manifesta na falta de apoio através de modos deficientes de solicitude. Assim, o cuidado inautêntico surge a partir da grande dificuldade de algumas trabalhadoras em percorrerem a 
instituição em busca do paciente fonte para a realização da coleta de exames laboratoriais bem como situações de constrangimento envolvendo os familiares desse paciente.

As dificuldades assinaladas pelo Dasein estão permeadas por questões burocráticas, ainda não resolvidas pelas instituições de saúde, como os problemas advindos da dificuldade apontada por algumas trabalhadoras para a efetivação da comunicação do acidente de trabalho. São apontada falhas no processo de atendimento, bem como o desconhecimento dos fluxos a serem seguidos, o que leva a não notificação por parte de muitas trabalhadoras.

Torna-se evidente neste estudo, a subnotificação dos acidentes, que dificultam a visualização do montante de exposições ocupacionais que ocorrem nos serviços de saúde dificultando o desenvolvimento de estratégias de prevenção que estejam atreladas com a realidade dos trabalhadores de enfermagem.

O acidente de trabalho com fluido biológico deve ser considerado não apenas como uma ocorrência no sistema de notificação, mas um fenômeno que se abre para um ser presente em um mundo que necessita de cuidado autêntico, para compreender a instabilidade da existência e superar esse momento reconstruindo seu processo de trabalho.

O ser-aí não alcança isso sozinho, ele só existe num mundo rodeado pelos outros, sendo assim ele necessita de apoio institucional, psicológico, emocional. Precisa conhecer seus direitos trabalhistas e ter respaldo legal. Sendo assim, questões como à diminuição da sobrecarga de trabalho devem ser revistas visando melhores práticas no ambiente laboral, integração entre as equipes de saúde e a adoção de práticas preventivas.

Desta maneira cabe aos gerentes de enfermagem e as instituições de saúde como um todo, assumirem suas posições em relação ao cuidado do trabalhador, estes cuidados devem ser integrados desde sua chefia imediata 
até a equipe de saúde ocupacional mantendo os fluxos de atendimento claros, objetivos e visíveis a todos os trabalhadores.

As políticas institucionais que advém de um sistema falho de saúde pública mecanizam os sujeitos e dificultam o olhar para o outro em sua magnitude. Políticas devem ser direcionadas para a prevenção dos acidentes, mas partindo do olhar sobre a essência do sujeito, partindo do apelo do ser pelo cuidado autêntico baseado na solicitude e na compreensão.

Identificou-se nesta pesquisa que embora a assistência à trabalhadora acidentada no que concerne ao acompanhamento clínico e ambulatorial tenha sido cumprida através do protocolo de atendimento, ele não aborda questões consideradas fundamentais no ponto de vista do sujeito que sofre 0 acidente.

Desse modo, considerando que esta pesquisa buscou vislumbrar o fenômeno a partir do sujeito, observo que a assistência prestada à trabalhadora de enfermagem que sofre acidente com material biológico não é efetiva, no que tange as peculiaridades dos sujeitos, pois traz à tona dificuldades relacionadas ao pós-acidente e questões obsoletas como o medo da demissão e o desconhecimento dos direitos trabalhistas por parte das trabalhadoras que necessitam ser esclarecidas pelas instituições.

Acredito que nas instituições de saúde, a cotidianidade afasta a visão de que o trabalhador de enfermagem é um ser com suas particularidades e não apenas mão de obra para o cuidado. É necessário combater os preconceitos, reconhecer que somos sujeitos próprios em nossa essência e que existimos nesse mundo de cuidado ao outro.

Ao encontrar o modo de existir da presença após o acidente, as trabalhadoras passam a identificar em seu cotidiano laboral as situações de vulnerabilidade e risco. O ser-aí passa então a praticar o autocuidado e é a partir daí que a assistência de enfermagem prestada por essas trabalhadoras torna-se efetiva, porque para cuidarmos dos outros precisamos nos cuidar. A 
reconstrução de seu processo de trabalho propicia ambientes laborais saudáveis e a reflexão acerca da exposição ocupacional torna-as capazes de repensar suas práticas e reconhecer a seriedade da questão. 
8. REFERENNCIAS 
Almeida ANG, Tipple AFV, Souza AC, Brasileiro AE. Risco biológico entre os trabalhadores de enfermagem. Rev. enferm. UERJ. 2009; 17(4): 595-00.

Alves SSM, Passos JP, Tocantins FR. Acidentes com perfuro cortantes em trabalhadores de enfermagem: uma questão de biossegurança. Rev. enferm. UERJ. 2009; 17(3): 373-7.

Araújo TM, Barros LM, Caetano JÁ, Araújo FN, Ferreira Júnior FC, Lima ACF. Acidente ocupacional e contaminação pelo HIV: sentimentos vivenciados pelos profissionais de enfermagem. R. pesq: cuid. fundam. Online. 2012; 4(4):2972-79.

Azadi A, Anoosheh M, Delpisheh A.Frequency and barriers of underreported needlestick injuries amongst Iranian nurses, a questionnaire survey. J Clin Nurs. 2011; 20(3-4):488-93.

Bahadori M, Sadigh G.Occupational Exposure to Blood and Body Fluids. Int J Occup Environ Med. 2010; 1 (1):1-10.

Balsamo AC, Felli VEA. Estudo sobre os acidentes de trabalho com exposição aos líquidos corporais humanos em trabalhadores da saúde de um hospital universitário.Rev.Latino-am Enfermagem. 2006; 14(3):346-53.

Baptista PCP, Merighi MAB, Freitas GF.El estúdio de La fenomenologia como uma via de acesso a la mejora de lós cuidados de enfermería.Cultura de los cuidados.2011;Ano XV-n 29.

Benatti MCC, Almeida CAF. Exposições ocupacionais por fluidos corpóreos entre trabalhadores da saúde e sua adesão à quimioprofilaxia. Rev Esc Enferm USP.2007; 41(1):120-6.

Brasil. Ministério do Trabalho e Emprego (BR). Portaria no 3.214 de 08 de Junho de 1978. NR09 - Programa de Prevenção de Riscos Ambientais. Disponível em: http://portal.mte.gov.br/legislacao/normas-regulamentadoras1.htm 
Brasil. Ministério do Trabalho e Emprego (BR). Portaria № 3.214 de 08 de Junho de 1978. NR6- Equipamento de proteção individual. Disponível em: http://portal.mte.gov.br/legislacao/normas-regulamentadoras-1.htm

Brasil. Ministério da Previdência Social. Lei №8. 213 de 24 de Julho de 1991. Dispõe sobre os Planos de Benefícios da Previdência Social e dá outras providências. Diário Oficial da União, Brasília, 24 jul. 1991.

Brasil. Ministério da Saúde. Portaria n. 3.120, de $1^{\circ}$ de julho de 1998. Aprova a Instrução Normativa de Vigilância a Saúde do Trabalhador no SUS. Diário Oficial da União, Brasília, 07 jul. 1998. Seção 1, p. 36.

Brasil. Ministério da Saúde. Portaria GM n.777, de 28 de abril de 2004. Dispõe sobre os procedimentos técnicos para a notificação compulsória de agravos à saúde do trabalhador em rede de serviços sentinela específica, no Sistema Único de Saúde - SUS.In: Brasil. Ministério da Saúde.Brasília;2004.

Brasil. Ministério da Saúde. "Recomendações para Atendimento e Acompanhamento de Exposição Ocupacional a Material Biológico: HIV e Hepatites B e C. Brasília; 2004. Disponível em http://www.aids.gov.br/sites/default/files/manual_acidentes_final_0.pdf

Brasil. Ministério do Trabalho e Emprego (BR). Portaria oo 485 de 11 de novembro de 2005. NR32 - Segurança e Saúde no Trabalho em Serviços de Saúde. Disponível em: http://portal.mte.gov.br/legislacao/normasregulamentadoras-1.htm

Brasil. Ministério da Saúde. Secretaria de Atenção à Saúde. Departamento de Ações Programáticas. Exposição a materiais biológicos. 2006

Brevidelli MM, Cianciarullo TI. Fatores psicossociais e organizacionais na adesão as precauções-padrão. Rev Saúde Pública. 2009;43(6):907-16

Castro MR, Farias SNP. Repercussões do acidente com perfurocortantes para a enfermagem: uma construção a partir do grupo focal. Esc Anna Nery Rev Enferm.2009;13 (3): 523-29. 
Centers for Disease Control e Prevention. Isolation techniques for use in hospitals. DHEW Publication, no. PHS, p. 70-2054, 1970.

Centers for disease Control and Prevention.Guidelines for the Management of Occupational Exposures to HBV, HCV, and HIV and Recommendations for Postexposure Prophylaxis.Estados Unidos da América.2001.Disponível em: http://www.cdc.gov.

Centers for disease Control and Prevention. Guidelines for the Management of Occupational Exposures to HIV and Recommendations for Postexposure Prophylaxis. Estados Unidos da América.2005.Disponível em: http://www.cdc.gov.

Claudio CV, Sarquis LMM, Scussiato LA, Miranda FMD. Monitoramento biológico sob a ótica dos enfermeiros gerentes. Rev Rene. 2013; 14(2):252-61.

Damasceno AP, Pereira MS, Souza ACS, Tipple AFV, Prado MA. Acidentes ocupacionais com material biológico: a percepção do profissional acidentado. Rev Bras Enferm. 2006; 59(1):72-7.

Diniz NMF, Lopes RLM, Silva JMO. Fenomenologia. Rev Bras Enferm. 2008;61(2): 254-7.

Duarte MR, Rocha SS. As contribuições da filosofia Heideggeriana nas pesquisas sobre o cuidado em enfermagem. Cogitare Enferm. 2011; 16(2):361-4.

Felli VEA, Tronchin DMR. A qualidade de vida no trabalho e a saúde do trabalhador de enfermagem. In: Kurcgant $\mathrm{P}$, organizadora. Gerenciamento em enfermagem. Rio de Janeiro: Guanabara Koogan;2011.p 85-103.

Fica AC, Jemenao MIP, Ruiz G, Larrondo M, Hurtado C, Munõz G, Sepulveda C. Accidentes de riesgo biológico entre Estudiantes de Carreras de La salud.Cinco anõs de experiência. Rev Chil Infect. 2010; 27 (1): 34-39. 
Garner P, Salehi AS. Occupational injury history and universal precautions awareness: a survey in Kabulhospital staff. BMC Infectious Diseases 2010, 10:19.

Giomo DB, Freitas FCT, Alves LA, Robazzi MLCC. Acidentes de trabalho, riscos ocupacionais e absenteísmo entre trabalhadores de enfermagem hospitalar.Rev.enferm.UERJ.2009;17(1):24-9.

Giri P, Basu S, Adisesh A, Rimmer A. Blood and body fluid exposures: consent for source patient testing. Occup Med (Lond). 2013 Mar;63(2):135-7.

Gomes AC, Agy LL, Malaguti SE, Canini SRMS, Cruz EDA, Gir E. Acidentes ocupacionais com material biológico e equipe de enfermagem de um Hospitalescola. Rev. enferm. UERJ 2009; 17(2): 220-3

Gusmão GS, Oliveira AC, Gama CS. Acidente de trabalho com material biológico: análise da ocorrência e do registro. Cogitare Enferm. 2013; 18(3):558-64.

Heiddeger M. Ser e Tempo. Trad.revisada de Marcia de Sá Cavalcante Schuback. 7ª̣ed. Petrópolis: Vozes;2012.

Inwood MJ. Dicionário Heidegger. Rio de Janeiro: Jorge Zahar, 2002.

Josgrilberg RS. O método fenomenológico e as ciências humanas. In: Castro DSP et al.,organizadora. Fenomenologia e análise do existir. São Paulo: Umesp; 2000.

Julio RS, Filardi MB, Marziale MHP. Acidentes de trabalho com material biológico ocorridos em municípios de Minas Gerais. Rev Bras Enferm. 2014 jan-fev; 67(1): 119-26.

Laurell AC, Noriega M.O processo de produção e saúde: trabalho e desgaste operário. São Paulo: Hucitec,1989. 
Loureiro LA, Gomes AC, Malaguti SE, Canini SRMS, Machado AA, Gir E. Adesão de profissionais de enfermagem ao seguimento clínico após exposição ocupacional com material biológico. Rev. Eletr. Enf. [Internet]. 2009;11(2):303-8.

Lubenow JAM, Moura MEB, Nunes BMVT, Figueiredo MLF, Sales LC. Representações sociais dos acidentes com materiais perfurocortantes.Rev Lat Am Enfermagem. 2012; 20(6): 1176-1185.

Maganini MAM, Rocha SA, Ayres JA. O significado do acidente de trabalho com material biológico para os profissionais de enfermagem. Rev Gaúcha Enferm. 2011;32(2):302-8.

Malaguti SE, Hayashida M, Canini SRMS, Gir E. Enfermeiros com cargos de chefia e medidas preventivas à exposição ocupacional: facilidades e barreiras. Rev Esc Enferm USP 2008;42 (3):496-503.

Malaguti-Toffano SE, Lopes LP, Facchin LT, Gir E. Crenças de enfermeiros quanto à transmissão ocupacional dos vírus da hepatite B e C. R. Enferm. Cent. O. Min. 2012; 2(2):195-202.

Marziale MHP, Santos HEC, Cenzi CM, Rocha FLR, Trovó MEM. Consequências da exposição ocupacional a material biológico entre trabalhadores de um hospital universitário. Escola Anna Nery Revista de Enfermagem. 2014 18(1).

Marziale MHP, Nishimura KYN. Programa preventivo para a ocorrência de acidentes com material perfuro-cortante entre trabalhadores de enfermagem de um hospital do estado de São Paulo. Acta Paul Enf,2003; 16(4): 59-68.

Marziale MHP. Subnotificação de acidentes com perfurocortantes na enfermagem. Rev Bras Enferm. 2003;56(2):164-168

Mbaisi EM, Ng'ang'a Z. Wanzala P, Omolo J. Prevalence and factors associated with percutaneous injuries and splash exposures among health-care workers in provincial hospital,Kenya.Pan African Medical Journal.2013;14:10. 
Naderi HR, Sheybani F, Bojdi A, Mostafavi I, Khosravi N. Occupational exposure to blood and other body fluids among health care workers at a university hospital in Iran. Workplace Health Saf. 2012 Oct;60(10):419-22.

Napoleão AA, Robazzi MLCC. Acidentes de trabalho e subnotificação entre trabalhadores de enfermagem. Rev Enferm UERJ. 2003;11:59-63.

Neves HCC, Souza ACS, Medeiros M, Munari DB, Ribeiro LCM, Tipple AFV. Segurança dos trabalhadores de enfermagem e fatores determinantes para adesão aos equipamentos de proteção individual. Rev. Latino-Am. Enfermagem. 2011; 19(2):[8 telas].

Nichiata LYI, Gir E, Takahashi RF, Ciosak SI. Evolução dos isolamentos em doenças transmissíveis: os saberes na prática contemporânea. Rev Esc Enferm USP.2004;38(1):61-70.

Oliveira AC, Gonçalves JA. Acidente ocupacional por material perfurocortante entre profissionais de saúde de um Centro Cirúrgico. Rev Esc Enferm USP.2010;44(2):482-7.

Oliveira AC, Paiva MHRS. Analysis of occupational accidents with biological material among professionals in pre-hospital services. Rev Lat Am Enfermagem.2013; 21(1): 309-315.

Pinheiro J, Zeitoune RCG. Hepatite B: Conhecimento e medidas de biossegurança e a saúde do trabalhador de enfermagem. Esc Anna Nery Rev Enf, 2008;12(2): 258-64

Pinheiro J, Zeitoune RCG. O profissional de enfermagem e a realização do teste sorológico para hepatite B. Rev. enferm. UERJ. 2009; 17(1):30-4

Quinn MM, Markkanen PK, Galligan CJ, Kriebel D, Chalupka SM, Kim H, Gore RJ, Sama SR, Laramie AK, Davis L. Sharps injuries and other blood and body fluid exposures among home health care nurses and aides. Am $\mathrm{J}$ Public Health. 2009 Nov;99 Suppl 3:S710-7 
Reé J. Heidegger.História e verdade em Ser e Tempo.São Paulo: UNESP,2000.

Ribeiro LCM, Souza ACS, Neves HCC, Munari DB, Medeiros M, Tipple AFV. Influência da exposição a material biológico na adesão ao uso de equipamentos de proteção individual. Cienc Cuid Saude. 2010; 9(2):325-332.

Sailer GC, Marziale MHP. Vivência dos trabalhadores de enfermagem frente ao uso dos antiretrovirais após exposição ocupacional a material biológico. Texto Contexto Enferm. 2007; 16(1): 55-62.

Santos, NJS, Monteiro ALC, Ruiz EAC. The first case of AIDS due to accupational exposure in Brazil. The Brazilian Journal of Infectious Diseases. 2002;6(3):140-141.

Sales CA. O ser-no-mundo e o cuidado humano. Rev. enferm. UERJ.2008; 16(4):563-8.

Sarquis LMM,Felli VEA, Mantovani MF,Miranda FMDA, Shiraiwa PC. A adesão ao protocolo de monitoramento biológico entre trabalhadores de saúde.Ciencia y Enfermeria.2009; XV (2): 107-113

Sarquis LMM, Felli VEA. Os sentimentos vivenciados após exposição ocupacional entre trabalhadores de saúde: fulcro para repensar o trabalho em instituições de saúde. Rev Bras Enferm. 2009; 62(5): 701-4

Silva,AID,Machado JMH, Santos EGOB, Marziale MHP.Acidentes com material biológico relacionados ao trabalho: uma análise institucional. Rev. bras. Saúde ocup., 2011, 36 (124): 265-273.

Simão, SAF, Souza V, Borges RAA, Soares CRG, Cortez EA. Fatores associados aos acidentes biológicos entre profissionais de enfermagem.Cogitare enferm. 2010; 15(1):87-91. 
Soares LG, Sarquis LMM, Kirchhofll ALC, Felli VEA. Multicausalidade nos acidentes de trabalho da Enfermagem com material biológico.Rev Bras Enferm. 2013; 66(6): 854-9.

Spagnuolo RS, Baldo RCS, Guerrini IA. Análise epidemiológica dos acidentes com material biológico registrados no Centro de Referencia em Saúde do trabalhador-Londrina- PR. RevBras Epidemiol.2008; 11(2): 315-23.

Stein E. Seis Estudos sobre "Ser e Tempo". 4ed. Petrópolis: Vozes, 2008.

Valim MD, Marziale MHP. Notification of work accidents with exposure to biological material: cross study. Online braz. j. nurs.2012;11(1).

van Wijk PTL, Schneeberger PM, Heimeriks K, Boland GJ, KaragiannisI,GeraedtsI,RuijsWLM.Occupational blood exposure accidents in the Netherlands. Eur J Public Health. 2010 20(3):281-7.

Vieira M, Padilha MICS. O HIV e o trabalhador de enfermagem frente ao acidente com material perfuro cortante. Rev Esc Enferm USP. 2008; 42(4):804-10.

Vieira M, Padilha MI, Pinheiro RDCP. Análise dos acidentes com material biológico em trabalhadores da saúde. Rev.Latino-Am.Enfermagem.2011;19(2).

Werle MA. A angústia, o nada e a morte em Heidegger. Transformação: Revista de Filosofia São Paulo. 2003; 26(1): 97-113. 
9. APENNDICES 
Apêndice 1. Roteiro de entrevista com profissionais de enfermagem que sofreram acidente com fluido biológico.

Caracterização dos Participantes da pesquisa.

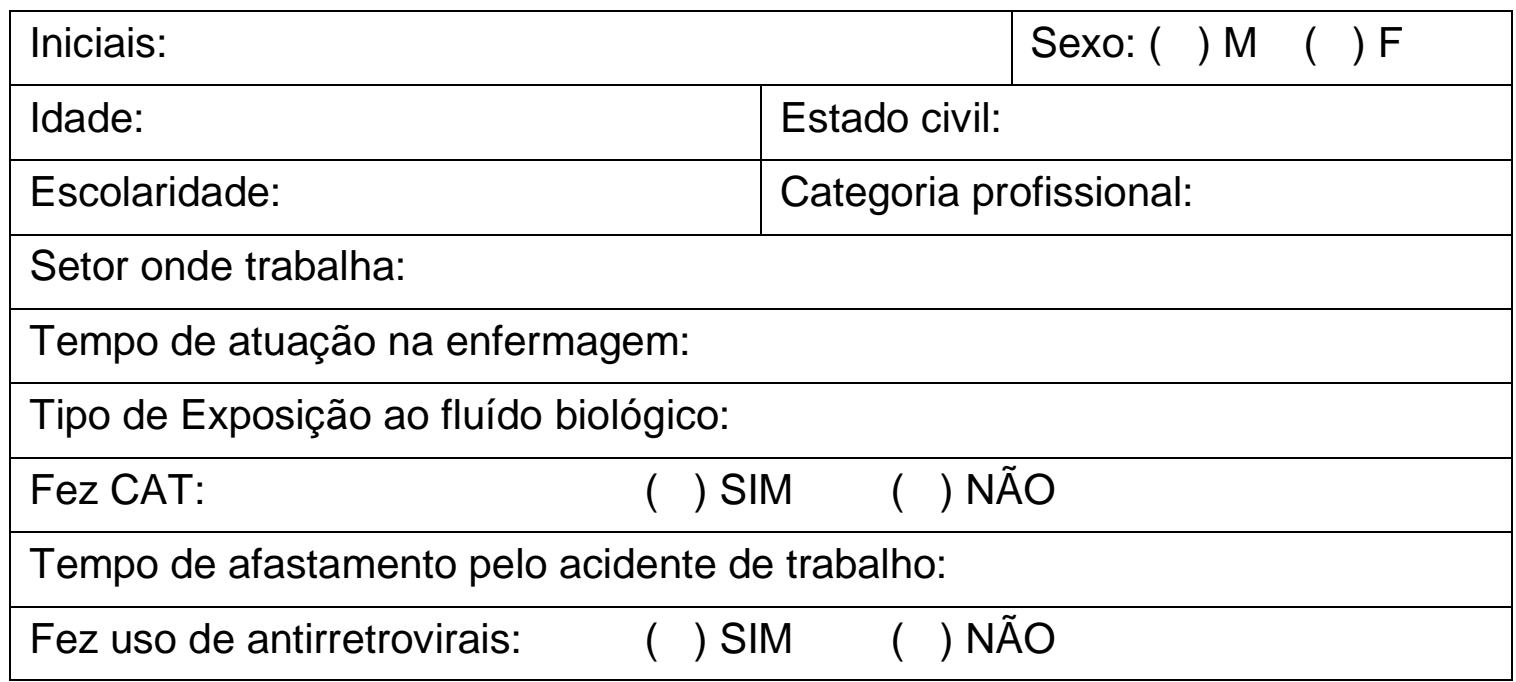

\section{Questão Norteadora:}

"Conte-me como foi para você ter se acidentado com fluido biológico?".

\section{Questão auxiliar:}

"Como foi à assistência que você recebeu após o acidente?". 
Apêndice 2. Termo de Consentimento Livre e Esclarecido

Título da Pesquisa: A vivência dos trabalhadores de enfermagem que sofreram acidente com fluido biológico: um olhar fenomenológico.

\section{Identificação dos pesquisadores.}

Pesquisadora: Carolina Luiza Bernardes

Tel: 991812409 e-mail: caluiza@usp.br

Cargo/função: Mestranda do Programa Pós Graduação em Gerenciamento em Enfermagem da Escola de Enfermagem da Universidade de São Paulo

Orientadora: Prof ${ }^{\mathrm{a}} \mathrm{Dr}^{\mathrm{a}}$ Patrícia Campos Pavan Baptista

Tel: 999525991 e-mail: pavanpati@usp.br

Cargo/ função: Profa Drª do Departamento de Orientação Profissional da Escola de Enfermagem da Universidade de São Paulo.

\section{Explicações ao participante sobre a pesquisa}

Gostaria de convidá-lo (a) a participar da presente pesquisa, que tem como objetivo compreender a experiência da assistência aos trabalhadores de enfermagem que sofreram acidente com fluido biológico, considerando suas necessidades de cuidado. Compreender a assistência prestada aos trabalhadores de enfermagem que se acidentaram com fluidos biológicos poderá desvelar o sentido do acidente para o trabalhador no tocante à assistência recebida fornecendo subsídios para o desenvolvimento de medidas de proteção à saúde do trabalhador.

Sua participação nesta pesquisa é voluntária. O senhor (a) possui o direito de retirarse deste estudo no momento que the for conveniente e em momento algum isto the trará prejuízos. Caso o senhor (a) ainda não tenha sido assistido após o acidente nós o encaminharemos ao Serviço Especializado em Engenharia de Segurança e em Medicina do Trabalho (SESMT) para o seu atendimento e acompanhamento. Quaisquer dúvidas acerca dessa pesquisa poderão ser esclarecidas pela pesquisadora e/ou orientadora. Este termo será elaborado em duas vias, uma delas ficará com o sujeito e a outra com a pesquisadora.

As entrevistas serão gravadas em aparelho de MP3, terão a duração de aproximadamente 40 minutos e serão realizadas durante o mês de Fevereiro de 2014 . Os dados da presente pesquisa serão registrados, posteriormente lidos e analisados e 
divulgados em periódicos e eventos científicos, porém em nenhum momento seu nome constará nesta pesquisa ou na divulgação dos resultados.

III. Esclarecimentos dados pelo pesquisador sobre garantias ao sujeito da pesquisa:

1. Acesso a qualquer tempo às informações sobre a pesquisa.

2. Liberdade para retirar seu consentimento a qualquer momento e deixar de participar do estudo, sem que isto lhe traga qualquer prejuízo.

3. Salvaguarda a sua confidencialidade, sigilo e privacidade.

\section{Identificação da Comissão de Pesquisa da EEUSP}

Endereço: Av. Professor Dr Enéas de Carvalho Aguiar, 419 CEP: 05403-000

São Paulo - SP. Telefone: 3061-7548 T-mail: edipesq@usp.br

V. Dados de identificação do participante da pesquisa.

\begin{tabular}{|l|l|l|}
\hline Nome: & \multicolumn{2}{|l|}{} \\
\hline RG: & Sexo: & Data de nascimento: \\
\hline Endereço: & Bairro: \\
\hline CEP: & Telefones: \\
\hline
\end{tabular}

\section{Consentimento Livre e Esclarecido}

"Declaro que, após convenientemente esclarecido pelo pesquisador e entendimento do que me foi explicado, consinto em participar da presente pesquisa"

São Paulo, de. de 2014

Assinatura do respondente

Assinatura da pesquisadora 
10. ANEXOS

$=$


Anexo 1. Parecer do Comitê de Ética em Pesquisa da Escola de Enfermagem da Universidade de São Paulo

\section{ESCOLA DE ENFERMAGEM DA UNIVERSIDADE DE SÃO PAULO - EEUSP}

\section{PARECER CONSUBSTANCIADO DO CEP}

\section{DADOS DO PROJETO DE PESQUISA}

Título da Pesquisa: A vivência dos trabalhadores de enfermagem que sofreram acidente com fluido biológico: um olhar fenomenológico

Pesquisador: CAROLINA LUIZA BERNARDES

\section{Área Temática:}

Versão: 2

CAAE: 20701313.8 .0000 .5392

Instituição Proponente: Escola de Enfermagem da Universidade de São Paulo - EEUSP

Patrocinador Principal: FUNDACAO DE AMPARO A PESQUISA DO ESTADO DE SAO PAULO

\section{DADOS DO PARECER}

Número do Parecer: 464.028

Data da Relatoria: $19 / 11 / 2013$

Apresentação do Projeto:

A exposição ocupacional aos fluidos biológicos é inerente ao trabalho desempenhado pela equipe de enfermagem durante a realização da assistência, na execução de procedimentos invasivos e cuidados diretos ao paciente tornando o trabalhador susceptivel a ocorrência de acidentes e exposto aos líquidos corporais que podem conter diferentes patógenos causadores de doenças como HIV, Hepatite B e C. Tratase

de um estudo de natureza qualitativa que pretende compreender a vivência do trabalhador de enfermagem após ter se acidentado com fluido biológico.

Objetivo da Pesquisa:

Este estudo tem como objetivo compreender a vivência dos trabalhadores de enfermagem que sofreram acidente com fluido biológico, considerando suas necessidades de cuidado.

Avaliação dos Riscos e Beneficios:

Riscos: O pesquisador classifica o projeto como risco minimo

Endereço: Av. Dr Enéas de Carvalho Aguiar, 419

Bairro: Cerqueira Cesar

UF: SP

Telefone: (11)3061-7548 Fax: (11)3061-7548 E-mail: edipesq@usp.br 


\section{ESCOLA DE ENFERMAGEM DA UNIVERSIDADE DE SÃO PAULO - EEUSP}

Continuaçắo do Parecer. 464.028

Benefícios: Fornecer subsídias para a desenvolvimento de medidas de proteção à saúde do trabalhador, indicando as possiveis lacunas no processo de atendimento que podem favorecer a subnotificação desses acidentes bem como o não seguimento do tratamento por parte dos trabalhadores tendo em vista a melhoria da assistência aos trabalhadores vitimados com esta natureza de acidente e o desenvolvimento de estratégias para a criação de um sistema eficaz de vigilância e monitoramento dos acidentes de trabalho com fluidos biológicos.

\section{Comentários e Considerações sobre a Pesquisa:}

Pesquisa que será realizada para desvelar o fenômeno de ser trabalhador de enfermagem e ter se acidentado com fluido biológico, considerando a lacuna existente sobre a assistência prestada ao trabalhador acidentado e suas repercussões. Tema relevante para área.

\section{Considerações sobre os Termos de apresentação obrigatória:}

- A solicitação de retirada da frase do TCLE: "indicando as possiveis lacunas no processo de atendimento que podem favorecer a sub notificação dos acidentes, bem como o não seguimento do tratamento por parte dos trabalhadores, tendo em vista a melhoria da assistência aos trabalhadores..." foi realizada.

- O tempo estimado de cada entrevista foi adicionado ao TCLE conforme solicitadoi : 40 minutos.

\section{Recomendaçōes:}

nada a declarar

Conclusões ou Pendências e Lista de Inadequações:

solicitações solicitadas, em parecer anterior, foram realizadas por parte do pesquisador (vide acima)

\section{Situação do Parecer:}

Aprovado

Necessita Apreciação da CONEP:

Não

Considerações Finais a critério do CEP:

A aprovação deste CEP não substitui a autorização prévia da instituição co-participante, para o início da coleta de dados.

Reitera-se a necessidade de registro de relatório com os resultados da pesquisa na Plataforma Brasil.

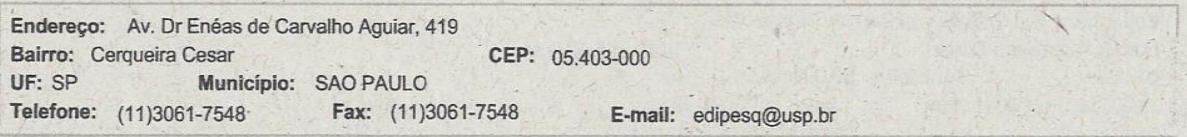




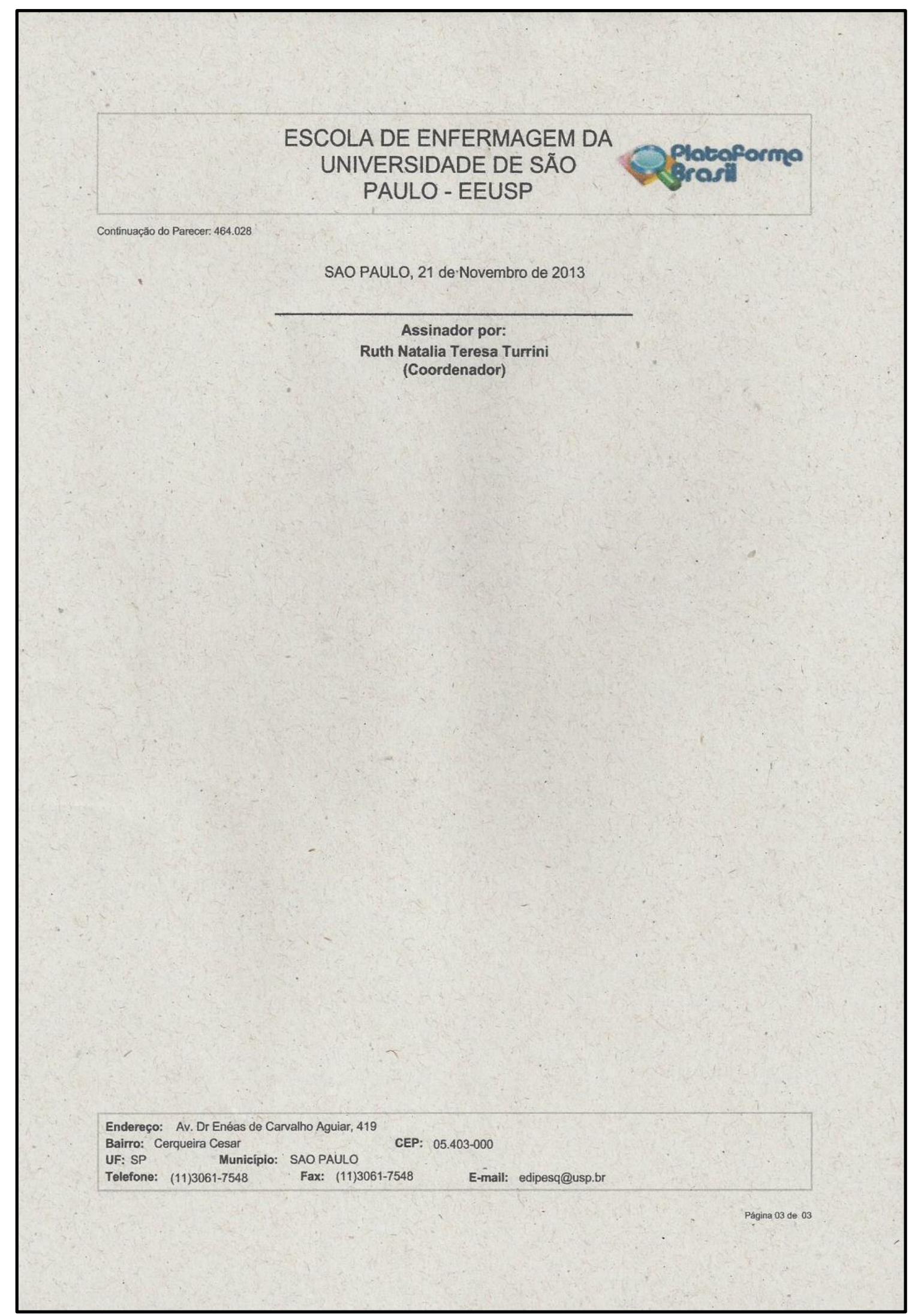

Endereço: Av. Dr Enéas de Carvatho Aguvar, 419

Telefone: (11)3061-7548 
Anexo 2. Declaração de Anuência e Termo de Compromisso da Instituição Coparticipante.

\section{DECLARAÇÃO DE ANUÊNCIA E TERMO DE COMPROMISSO DA INSTITUIÇÃO CO-PARTICIPANTE}

Vimos pelo presente manifestar nosso apoio ao projeto de pesquisa objeto desse documento, coordenado pela Profa Dra Patricia Campos Pavan Baptista,da Escola de Enfermagem, da Universidade de São Paulo, por entendermos que se trata de iniciativa que vem ao encontro dos esforços que temos desenvolvido neste Hospital das Clínicas da Faculdade de Medicina da Universidade de São Paulo (HCFMUSP) no sentido de melhor atender os funcionários, no que diz respeito ao atendimento dos trabalhadores de enfermagem que se acidentam com fluido biológico.

Nestes termos, o Serviço Especializado em Engenharia de Segurança e Medicina do Trabalho (SESMT) do Hospital das Clínicas da Faculdade de Medicina da Universidade de São Paulo (HCFMUSP), representado pelo seu Coordenador, Eduardo Costa Sá, declara para os devidos fins e efeitos de direito que apoia e autoriza a participação do SESMT na realização da pesquisa abaixo citada, com os funcionários da equipe de enfermagem desse hospital:

A vivência dos trabalhadores de enfermagem que sofreram acidente com fluido biológico: um olhar fenomenológico. Pesquisador responsável Carolina Luiza Bernardes, aluna de Mestrado da Escola de Enfermagem da Universidade de São Paulo (EE-USP). Projeto cadastrado na Plataforma Brasil ainda em edição, para posterior apreciação pelo CEP.

O SESMT-HCFMUSP declara que conhece e que cumprirá os requisitos da Resolução n 196, de 10 de outubro de 1996, do Conselho Nacional de Saúde, e suas complementares, e compromete-se a utilizar os materiais e dados coletados exclusivamente para os fins previstos no protocolo da pesquisa acima descrita. 
O SESMT-HCFMUSP e a EE-USP estão cientes que o propósito do estudo é contribuir para desvelar o sentido do acidente para o trabalhador no tocante à assistência recebida fornecendo subsídios para o desenvolvimento de medidas de proteção à saúde do trabalhador, indicando as possíveis lacunas no processo de atendimento que podem favorecer a subnotificação desses acidentes bem como o não seguimento do tratamento por parte dos trabalhadores tendo em vista a melhoria da assistência aos trabalhadores vitimados com esta natureza de acidente e o desenvolvimento de estratégias para a criação de um sistema eficaz de vigilância e monitoramento dos acidentes de trabalho com fluidos biológicos, assunto de relevância e interesse para o HCFMUSP.

São Paulo, 26 de Setembrade 2013.

Dr. Equardo costasa

Coordenador do SESMT-HCFMUSP 